PytlikZillig, L.M., Hamm, J.A., Shockley, E., Herian, M., Neal, T.M.S., Kimbrough, C., Tomkins, A.J., Bornstein, B.H. (2016). The dimensionality of trust-relevant constructs in four institutional domains: Results from confirmatory factor analyses. Journal of Trust Research, 6, 111-150. doi:10.1080/21515581.2016.1151359

(C) 2016 Taylor \& Francis

This is a pre-print version of the paper t published in the Taylor \& Francis journal. This version may not exactly replicate the final version published in the Taylor \& Francis journal. It is not the copy of record. Please visit the journal's website for more information:

http://www.tandfonline.com/doi/abs/10.1080/21515581.2016.1151359 


\title{
The Dimensionality of Trust-Relevant Constructs in Four Institutional Domains: Results from Confirmatory Factor Analyses
}

\author{
Lisa M. PytlikZillig, Joseph A. Hamm, Ellie Shockley, Mitchel N. Herian, Tess M.S. Neal, \\ Christopher D. Kimbrough, Alan J. Tomkins, \& Brian H. Bornstein
}

\begin{abstract}
**Lisa M. PytlikZillig, University of Nebraska Public Policy Center, 215 Centennial Mall South \#401, Lincoln, NE 68588-0228, Phone: 402-472-5678, Email: lpytlikz@nebraska.edu (**corresponding author)

Joseph A. Hamm, School of Criminal Justice \& Environmental Science and Policy Program, Michigan State University; 560 Baker Hall, 655 Auditorium Road, East Lansing, MI 48824; Phone: 517-355-6603; Email: jhamm@msu.edu
\end{abstract}

Ellie Shockley, University of Nebraska Public Policy Center, 215 Centennial Mall South \#401, Lincoln, NE 685880228, Phone: 773-240-5154, Email: ellie.shockley@gmail.com

Mitchel N. Herian, University of Nebraska Public Policy Center, 215 Centennial Mall South \#401, Lincoln, NE 68588-0228, Email: mnherian@nebraska.edu

Tess M.S. Neal, New College of Interdisciplinary Arts \& Sciences - SBS, Arizona State University, 4701 West Thunderbird Rd, Glendale AZ 85306; Phone: 402-472-5485; Email: tess.neal@asu.edu.

Christopher D. Kimbrough, Dept. of Psychology, 238 Burnett Hall, University of Nebraska-Lincoln, Lincoln, NE 68588-0308; Phone 360-927-1787; Email: christopher.kimbrough@ huskers.unl.edu

Alan J. Tomkins, University of Nebraska Public Policy Center, 215 Centennial Mall South \#401, Lincoln, NE 68588-0228, Phone: 402-472-5678, Email: atomkins@ nebraska.edu

Brian H. Bornstein, Dept. of Psychology, 236 Burnett Hall, University of Nebraska-Lincoln, Lincoln, NE 685880308; Phone 402-472-3721; Email: bbornstein2@unl.edu

\section{Acknowledgements and Funding}

This research was supported in part by the National Science Foundation (NSF) under Grant Numbers DGE-1154855, DGE-0903469, SES-1061635, SES- 1228559, SES-1353980, SBE-0965465, and SBES-1228937. Any opinions, findings, conclusions or recommendations expressed in this material are those of the authors and do not necessarily reflect the views of NSF. The authors declare no conflicts of interest. 


\begin{abstract}
Using confirmatory factor analyses and multiple indicators per construct, we examined a number of theoretically derived factor structures pertaining to numerous trust-relevant constructs (from 9 to12) across four institutional contexts (police, local governance, natural resources, state governance) and multiple participant-types (college students via an online survey, community residents as part of a city's budget engagement activity, a random sample of rural landowners, and a national sample of adult Americans via an Amazon Mechanical Turk study). Across studies, a number of common findings emerged. First, the best fitting models in each study maintained separate factors for each trust-relevant construct. Furthermore, post hoc analyses involving addition of higher-order factors tended to fit better than collapsing of factors. Second, dispositional trust was easily distinguishable from the other trust-related constructs, and positive and negative constructs were often distinguishable. However, the items reflecting positive trust attitude constructs or positive trustworthiness perceptions showed low discriminant validity. Differences in findings between studies raise questions warranting further investigation in future research, including differences in correlations among latent constructs varying from very high (e.g., 12 inter-factor correlations above .9 in Study 2 ) to more moderate (e.g., only 3 correlations above .8 in Study 4). Further, the results from one study (Study 4) suggested that legitimacy, fairness, and voice were especially highly correlated and may form a single higher-order factor, but the other studies did not. Future research is needed to determine when and why different higher-order factor structures may emerge in different institutional contexts or with different samples.
\end{abstract}

Keywords: Trust in institutions, dispositional trust, confidence, legitimacy, justice, fairness 


\section{The Dimensionality of Trust-Relevant Constructs in Four Institutional Domains: Results from Confirmatory Factor Analyses}

An impressive body of research on individuals' trust in specific institutions can be found across many disciplines, as many different kinds of public institutions rely on public trust (see, e.g., Bornstein \& Tomkins, 2015; Möllering, 2006; Shockley, Neal, PytlikZillig, \& Bornstein, 2015). Institutional efforts to promote public trust in U.S. institutions abound, ranging from the Obama Administration's Open Government Initiative designed specifically to "ensure the public trust" (Obama, 2009, p. para. 1), to the National Center for State Courts' Action Plan to "build public trust and confidence in the courts" (National Center for State Courts, 2000, p. 6). These efforts are perhaps not surprising, as public trust is considered essential for the functioning of democracy, effective and efficient governance, optimizing institutional productivity, and facilitating societal interactions (Bangerter, 2014; Newton, 2001; Vigoda-Gadot \& Mizrahi, 2014; Warren, 1999).

When examining trust in specific institutions, researchers and practitioners have varied widely in their reference to and measurement of specific constructs. Trust is often defined as a psychological state of the trustor characterized by willingness to rely upon, give control to, support, or otherwise be vulnerable to the trustee (see PytlikZillig \& Kimbrough, 2015, for a review). However, consistent with Metlay's (1999) observation that "the notion of trust comes in so many flavors, packages, and subspecies that it seems to have been swallowed up in a conceptual quagmire" (p. 100), the scholarship of trust does not stick closely to any common definition. Instead, it references a multitude of trust-related constructs, including the trustor's dispositional trust; willingness to support the institution; and perceptions of the institution's competence, benevolence, integrity, legitimacy, and so on; as well as a dizzying array of 
measures for each (Earle, 2010; McEvily \& Tortoriello, 2011).

The wide variety of trust-relevant constructs and measures is consistent with the idea that trust is multi-faceted and multidimensional (Kohring \& Matthes, 2007; Mayer, Davis, \& Schoorman, 1995; McKnight, Choudhury, \& Kacmar, 2002; Rousseau, Sitkin, Burt, \& Camerer, 1998), and with the breadth of constructs subsumed by definitions and conceptualizations of trust

(e.g., Castaldo, Premazzi, \& Zerbini, 2010; PytlikZillig \& Kimbrough, 2015). However, there are important gaps in the research on the relationships among the many constructs. As we review below, little empirical work has focused on systematically comparing and contrasting the substantial number of trust-relevant constructs in the literature (e.g., determining the number of dimensions they form and which are most and least similar to one another), or evaluating their relations under different conditions and in different contexts. However, clarifying these relationships is valuable to the advancement of both the theory and measurement of trust.

Our research contributes to understanding the dimensionality of trust-relevant constructs in specific institutional contexts, and the development of measures that might be used across contexts. From a theoretical perspective, there may be many, conceptually distinguishable, trustrelevant concepts. At the same time, from a measurement perspective, it may be the case that some of these conceptually-distinct constructs are statistically or practically indistinguishable. In this article, our examination of the structure and measurement of numerous trust-relevant constructs in four samples and across four contexts is our central contribution to the literature.

\section{A Myriad of Trust-Relevant Constructs}

In a review of trust-relevant constructs from the organizational literature, McEvily and Tortoriello (2011) identified 129 distinct measures in 171 studies and 38 conceptually (or 
potentially) distinct constructs within these measures. ${ }^{1}$ In the risk management literature, Earle (2010) identified a similarly large number of trust-relevant constructs in 132 studies, including constructs such as competence, care, shared values, general and specific trust, reliability, deference, doubt, and distrust. In considering the dimensionality of trust-relevant constructs, however, McEvily and Tortoriello (2011) and Earle (2010) take different stances. Earle begins by identifying a "consensus model" which he says represents the opinions of social science generally, and portrays trust as being "two- perhaps three-dimensional" (p. 541). In contrast, McEvily and Tortoriello (2011) argue that more research is needed to resolve the question of trust's dimensionality.

McEvily and Tortoriello also review five measures of trust that have been replicated in the organizational trust literature and shown to have reasonable psychometric properties (Cummings \& Bromiley, 1996; Currall \& Judge, 1995; Gillespie, 2003; Mayer \& Davis, 1999; McAllister, 1995). They note, however, that these five measures differ in how they resolve the question of dimensionality, with each measure focusing on somewhat different constructs. For example, whereas Mayer and Davis (1999) define and measure ability, benevolence, and integrity forms of trustworthiness, McAllister (1995) measures cognition- and affect-based types of trust which appear to relate respectively to cognitive evaluations of competence and reputation versus more affective and relational evaluations. Thus, McEvily and Tortoriello emphasize there remains an overarching need to specify what dimensions of trust are "distinct yet related" and to establish empirically and more concretely "the multi-dimensionality of trust" (p. 37). They also identify a need to examine such dimensions across different contexts and types of relationships.

\footnotetext{
${ }^{1}$ McEvily and Tortoriello (2011) and others often refer to "dimensions" but are not using the term dimensions as we do here (i.e., as indicating underlying structural and statistical relationships between the constructs). Many times, authors' use of the term "dimensions" refers to what we refer to as "constructs" in the present article.
} 
To date, much of the work on the dimensionality of trust-relevant constructs has been theoretical (e.g., Mayer et al., 1995; McKnight \& Chervany, 2001; PytlikZillig \& Kimbrough, 2015). Relatively few empirical studies have addressed the dimensionality of trust-relevant constructs in institutional contexts, and those that have done so only examined a few constructs at a time, or have measured constructs using few (sometimes single) items (e.g., Colquitt, 2001; Colquitt \& Rodell, 2011; Heyns \& Rothmann, 2015; Poortinga \& Pidgeon, 2003; Smith, Leahy, Anderson, \& Davenport, 2013). While conceptual distinctions can be and frequently are drawn between and among many of the trust-relevant constructs, it is impossible to know the dimensionality of constructs that were not measured in existing studies. Thus, it remains unclear whether or when these distinctions result in dimensions that can be distinguished consistently, statistically, and/or meaningfully. To begin to fill this gap, in the present research, we use multiple items to increase the internal reliability of construct measurement and confirmatory factor analyses to test whether theoretically important distinctions between trust-relevant constructs also hold statistically. In addition, we examine inter-construct correlations and post hoc models suggested by the data, to explore the meaningfulness of construct distinctions.

\section{Categories of Trust-Relevant Constructs}

We begin with a review of how trust-relevant constructs have been categorized - that is, common distinctions theorists have made and that may have implications for dimensionality. We also point out how these distinctions may apply to the items and measures used in our empirical inquiries. Table 1 illustrates how such distinctions translate into the statistical measurement models investigated in our research. ${ }^{2}$ Note that our discussion focuses on trust in specific

\footnotetext{
${ }^{2}$ Table 1 orders the models from most to least complex. Our discussion here orders the models somewhat differently, in an order that we feel makes it easier to connect the models to theory. For example, rather than organizing our discussion according to model complexity, we discuss the many factor model prior to discussing the
} 
institutions, as that is the focus of this inquiry. Similar distinctions may apply to other kinds of trust (e.g., interpersonal, organizational, or inter-organizational trust) but our studies do not include measures of those kinds of trust and thus may not generalize to them.

[Insert Table 1 about here]

Dispositional trust versus target-specific trust. Virtually all theories of trust include a distinction between the trustor's propensity or disposition to trust across targets, and attitudes toward or evaluations and expectations of a specific target (Colquitt, Scott, \& LePine, 2007; Mayer et al., 1995; Rousseau et al., 1998). See Table 1, model 2F, for a visual depiction of this distinction as it applies to constructs used in our studies. Dispositional trust is one's tendency to trust across a set of targets (e.g., to trust people in general, institutions in general, strangers). Dispositional trust constructs have also been described as propensity to trust, trait trust, and general or generalized trust (Frazier, Johnson, \& Fainshmidt, 2013; Nannestad, 2008; Rotter, 1980). Dispositional trust is measured in our studies with items such as "I would say that most people can be trusted in general" (an item adapted from one in the National Election Studies and the General Social Survey).

In contrast, we use the term institutional trust ${ }^{3}$ to refer to trust in one specific institutional target (e.g., "I trust [institution]"). Studies including measures of dispositional and institutional trust consistently reveal that it is easy to discriminate these two constructs statistically (e.g., Hamm, PytlikZillig, Herian, Bornstein, et al., 2013; Heyns \& Rothmann, 2015; Lubell, 2007). Dispositional trust is typically hypothesized to positively relate to institutional trust (Brehm \&

various ways of collapsing the many factors of trustworthiness, and beginning our discussion with what we perceive as the most frequently-cited organization of trustworthiness constructs.

${ }^{3}$ Note that institutional trust is not always used this way. For example, it is sometimes used to describe 'system trust' or refer to safeguards and policies that encourage trustors to rely upon trustees (Bachmann, 2011; Pennington, Wilcox, \& Grover, 2003; PytlikZillig \& Kimbrough, 2015), but this is not how we are using the term here. 
Rahn, 1997; Dietz \& Den Hartog, 2006; Levi, 1998; Mayer et al., 1995; Putnam, 2000), but empirical studies find the strength of the relationship varies (Heyns \& Rothmann, 2015; McKnight, Cummings, \& Chervany, 1998). For instance, in their cross-national analyses, Zmerli and Newton (2008) reported moderate-high correlations between institutional and dispositional trust. Uslaner (2002), on the other hand, found small associations between institutional and moral trust (a construct similar to dispositional trust) across multiple nations.

Trust versus trustworthiness. Another common distinction is between trust and trustworthiness - both of which are aimed at specific targets (unlike dispositional trust, which applies across targets). See Table 1 model 3F for a description of incorporating this distinction. As previously noted, trust per se is often viewed as a psychological state of the trustor characterized by willingness to rely upon, give control to, support, or otherwise be vulnerable to the trustee (Mayer et al., 1995; PytlikZillig \& Kimbrough, 2015; Rousseau et al., 1998). However, often, especially in national and other large scale surveys, trust is assessed by simply asking people to report directly how much overall "trust" they have in the trustee (e.g., Abramson \& Finifter, 1981; Craig, Niemi, \& Silver, 1990; Gillespie \& Mann, 2004)—leaving both the definition of trust and the bases for that trust unspecified for the respondent (thus, we refer to this as direct or unspecified trust). For example, items such as "I trust [institution] to perform its functions as it should" or "My confidence in [institution] is high," assess direct/unspecified trust. Other times, however, trust is assessed by explicitly asking people about their willingness to behaviorally support, give control to, rely upon, or otherwise be vulnerable to the trustee in general or specific ways (Gillespie, 2003; Mayer \& Davis, 1999). Some have also distinguished between a willingness to support that may be temporary and related to specific policies or actions of the institution, and more diffuse and resilient willingness to support that 
may withstand disappointments and fluctuations in satisfaction with the trustee (Easton, 1975; Gibson, Caldeira, \& Spence, 2003). We refer to this more resilient willingness to support as "loyal trust" and assess it with items that more specifically target the durability of one's trust, such as "I generally support [institution] even when I disagree with some of its decisions" and "I feel a sense of loyalty to [institution]."

In contrast to trust per se, trustworthiness refers to beliefs, evaluations, or expectancies of the target that are often theorized to form the basis for trust. While distinctions between trust and trustworthiness are commonly asserted as having theoretical importance (e.g., Mayer et al., 1995; Möllering, 2006; Sharp, Thwaites, Curtis, \& Millar, 2013), researchers also often indicate they are studying trust or dimensions of trust while assessing trustworthiness constructs instead (e.g., Gillespie \& Mann, 2004; Hoy \& Tschannen-Moran, 2003). Furthermore, from a measurement perspective, it is sometimes difficult to separate direct/unspecified measures of trust from measures of trustworthiness (e.g., Lubell, 2007), with correlations not uncommonly exceeding .80 (Gillespie \& Mann, 2004). Thus, although trust may be importantly distinct from trustworthiness from a theoretical perspective, to the extent that trust and trustworthiness (or at least certain of their operationalizations) are extremely closely related, their measurement becomes indistinct, such that measuring one of the constructs is also an increasingly good indicator of the other construct as well. Thus, it is not certain that all measures of trust and trustworthiness constructs will be statistically distinct.

Distinctions among trustworthiness constructs. The majority of the trust-related constructs in the literature are "trustworthiness" constructs (i.e., constructs that describe evaluations of features of the trustee that may make it "worthy" of trust). The many factor (MF) model in Table 1 describes a model in which each trustworthiness construct (as well as each trust 
and dispositional trust construct) is its own separate factor. As illustrated by the MF model, in the current research we include measures of up to 12 trust-relevant constructs ( 9 of which are trustworthiness constructs). However, most theories propose only 2-4 important trustworthiness constructs, suggesting that trustworthiness constructs might be reducible to a smaller number of dimensions or categories_-with the precise nature of those dimensions or categories varying across theoretical perspectives. Thus, we tested CFA models with the constructs distinct and combined along theoretically defensible lines.

Ability, benevolence, integrity. One of the most widely cited models of trust in the literature proposes that trustworthiness constructs include three dimensions: ability, benevolence, and integrity (Mayer et al., 1995). If these are the most basic of trustworthiness dimensions, then one might expect other features of the trustee that make it worthy of trust would fall into these categories. Using theory as our guide, we attempted to group our trustworthiness constructs into each of these types (see Table 1, model 5F). Ability refers to perceptions that the trustee has the competence and knowledge to fulfill or live up to the trustor's trust. Perceptions of legitimacythe institution's rightful and appropriate holding and use of power (Gau, 2012; Gibson et al., 2003; Gibson, Caldeira, \& Spence, 2005; Jackson \& Gau, 2015; Tyler \& Fagan, 2008; Tyler \& Huo, 2002) — may also reflect perceptions of ability because competency-based credentials and licenses are key means by which to improve perceptions of legitimacy (Tyler \& Huo, 2002). Benevolence refers to perceptions that the trustee is caring and holds goodwill toward the trustor. Items assessing perceptions of the trustee as caring are often used to assess benevolence (e.g., "For the most part, [institution] acts out of concern for the community"). In addition, we included "voice" in the benevolence category. Voice is the perception that the trustee will listen to and consider the views of others (De Cremer \& Alberts, 2004; Wu \& Wang, 2013). For 
example, an item such as "[Institution] listens to my opinions" addresses perceptions of voice. While voice is often is conceptualized as part of procedural fairness (Mentovich, Rhee, \& Tyler, 2014; Tyler, 2007-2008), listening to and taking the time to understand people's interests also may represent a manner by which care, respect, and concern can be shown to others (Tyler \& Lind, 1992) and thus may meet people's needs for connections and belongingness (Baumeister \& Leary, 1995; De Cremer \& Alberts, 2004).

Integrity refers to perceptions of the trustee's moral character. Dictionary definitions equate integrity with honest and moral qualities. Thus, an item such as "[Institution] is mostly made up of honest individuals" reflects perceived integrity. In addition to honesty, we include perceptions that the trustee is fair (e.g., "[Institution] generally has been fair in its dealings with the community") and unbiased (e.g., "The actions of [institution] are biased," reverse-coded) as part of integrity. Honesty, fairness, neutrality (as well as other characteristics like courage, determination, humility, self-control, and so on), are commonly seen as aspects of moral character or virtue (Cen \& Yu, 2014; Wren, 2014). Although fairness and neutrality/bias are more typically viewed as components of the broader construct of procedural justice (Blader \& Tyler, 2003; Burke \& Leben, 2007-2008), little research to date has investigated how such constructs relate to Mayer et al.'s (1995) three constructs (see Colquitt \& Rodell, 2011, for a rare such investigation).

Values as separate from integrity. Mayer et al. (1995) suggest that most qualities that are perceived as making a trustee "worthy" of trust are covered by their three categories (ability, benevolence, integrity). However, some have suggested other categories are also needed. For example, Pirson and Malhotra (2011) argue that, although Mayer et al. include it as part of integrity, "identification" based on perception of shared values is a separate form of 
trustworthiness that requires time to develop (see also Lewicki \& Bunker, 1995). We illustrate this potential distinction between integrity and shared values in Table 1 model $6 \mathrm{~F}$. We group cynical beliefs with shared values because it often reflects judgments that the institution does not represent one's values or interests (Tyler \& Huo, 2002). For example, an item used in our research to assess cynical beliefs was "[Institution] does not protect my interests."

Warmth versus ability. A number of researchers have divided trust constructs into those based on affective evaluations (e.g., of relational factors such as the trustee's intentions and benevolence), versus more cognitive evaluations (e.g., of institutions' abilities, competencies, reliability and ways of performing functions) (Jungermann, Pfister, \& Fischer, 1996; McAllister, 1995; Metlay, 1999; Rousseau et al., 1998). The division of trust into cognitive and affective types, and trustworthiness evaluations into those that are warm versus cold, or focused on relational versus calculative dimensions, appears to be roughly consistent with "universal" dimensions of social cognition (Fiske, Cuddy, \& Glick, 2007). Fiske et al. refer to these two universal dimensions as warmth (morality) and competence (ability), but note that, across various areas of study, they have been called by many other names including social and intellectual (Rosenberg, Nelson, \& Vivekananthan, 1968), sociability and responsibility (Fiske, 1980), liking and respecting (Fiske, Xu, Cuddy, \& Glick, 1999), social and task (Bales, 1999), and/or communion and agency (Wojciszke \& Abele, 2008). Just as prior research has sorted many person perception and trait variables into warmth and competence types (Fiske et al., 2007), it may also be possible to divide perceptions related to trustworthiness into two similarly corresponding types, for example, by collapsing Mayer et al.'s (1995) benevolence and integrity dimensions (see Table 1, model 4a). Supportive of such a collapse, some have noted that benevolence and integrity are difficult to discriminate early in a relationship and that the 
distinction may take time to develop (Mayer et al., 1995; Schoorman, Mayer, \& Davis, 2007).

Trustworthiness and distrust-worthiness. Finally, another potential organization for trustworthiness constructs (represented in Table 1 model $4 \mathrm{Fb}$ ) is suggested by a study of trust dimensionality by Poortinga and Pidgeon (2003). They examined seven constructs typically discussed in the risk domain using 11 items reflecting perceptions of government in relation to five specific risk policies (e.g., mobile phones, climate change). They consistently found a twodimensional structure of responses reflecting generally trusting views about characteristics of the institution (the government is caring, fair, competent, and transparent or open) and skeptical distrusting views about "how risk policies are brought about or enacted" (p. 961) - that is, skepticism or distrust regarding institutional actions reflecting a lack of integrity, credibility, and reliability. Their findings of positive and negative trustworthiness factors are consistent with other claims in the literature regarding the idea that trust and distrust are separate constructs rather than two ends of a single continuum (Dimoka, 2010; Lewicki, McAllister, \& Bies, 1998; Marsh \& Dibben, 2005; McKnight \& Choudhury, 2006).

\section{Potential Structural Variation across Contexts}

In addition to the theoretical distinctions described in the review above, some theory and prior research suggests that the structure of trust-relevant constructs could vary across people (trustors) or institutional contexts. For example, judging whether or not an institution or its members is/are honest, caring, competent, and so on requires some knowledge of the institution. Participants that lack sufficient knowledge or experience to make such distinctions (e.g., between benevolence and competence) may have attitudes that form a relatively global single-factor structure reflecting positive versus negative perceptions. Similarly, some have theorized that benevolence and integrity assessments may form one rather than two factors prior to much 
knowledge and experience with a trustee because integrity judgments are especially hard to make early in a trustor-trustee relationship (Mayer et al., 1995; Schoorman et al., 2007). In addition, the salience of different constructs may vary across contexts, which may impact structure. For example, although it is commonly noted that warmth (benevolence) judgments are more important than competence when it comes to predicting trust and liking, Wojciszke and Abele (2008) find that the more dependent one is upon another, the more that judgments of ability (competence) matter. Trust researchers, too, have suggested that trustworthiness dimensions can vary in importance depending on the nature or stage of a trustor-trustee relationship (Boersma, Buckley, \& Ghauri, 2003; Hamm, PytlikZillig, Herian, Bornstein, et al., 2013; Pirson \& Malhotra, 2007; Sheppard \& Sherman, 1998). Such differences in salience or importance could influence the institutional characteristics to which people closely attend, and thus impact the structure of measures of those characteristics.

\section{The Present Research}

As discussed, some distinctions between trust-relevant constructs are well-established (e.g., between dispositional and institutional trust), while others are not (e.g., between direct measures of trust and measures of trustworthiness), and others have not yet been extensively examined (e.g., distinctions between specific categories of trustworthiness constructs). In the present research, we analyzed data from four surveys of distinct participant groups (a college student sample, an urban community sample, a statewide random sample of rural land owners, and a national sample). We asked respondents to respond to a large number of trust-relevant constructs (9-12 constructs per sample) targeting four institutions in distinct contexts (the police, city government, natural resource management institutions, and state government), and used confirmatory factor analyses (CFA) to test potential latent structures of these institutional trust- 
relevant constructs, and distinctions between different sets of constructs suggested by the justreviewed prior research and theory. By comparing hypothesized covariance structures to the actual data covariance matrix, CFA allows researchers to test the relationships and distinctions necessary to best represent the covariance in the data. Thus, CFA provides an ideal methodology for identifying the dimensions necessary for explaining the covariance in responses to the various items (John \& Benet-Martinez, 2000; Kline, 2005). In the following, we describe the methods used across studies, and then report the methods and results specific to each individual study before discussing the results across studies.

Scales and items. The constructs we investigated, and the items we used to assess them, were influenced by both the prior literature and practical considerations. Items were initially drawn from a wide variety of sources (see Table 2 for a summary). For example, direct/unspecified and dispositional trust items were taken or adapted from the National Election Survey and General Social Survey and the International Personality Item Pool. Items for the trustworthiness and loyal trust constructs were based on reviews that we conducted of those specific constructs in the literature on institutional trust (including reviewing many of the measures identified by McEvily \& Tortoriello, 2011). However, most items were written or adapted to fit the differing targeted trustees and their specific contexts. For example, comparisons among items in tables 4, 7, 10, and 13 shows that we changed the object of the items according to the target of trust (e.g., police, government). In addition, some of the items were conceptually similar but contextually distinct. For instance, the legitimacy items for the local governance context include reference to fair elections, but in the police context the legitimacy items only include reference to fair selection (not election) of officers. For all of the studies, response scales for each item were on 6-point (Study 2) or 7-point (Studies 1, 3, and 4) 
scales ranging from strong disagreement to strong agreement. Individual items were, when appropriate, recoded to reflect the predominantly positive (i.e., reflecting high trust) or negative (i.e., reflecting distrust, in the case of perceived bias and cynical beliefs) nature of the scale.

Because we were drawing from existing data sets designed for other purposes (see methods of each study for their primary purposes), there is some diversity across our studies in both constructs measured and wording of specific items used in our measures. ${ }^{4}$ This diversity strengthens the current analysis, however, because it allows a test of the consistency of results at a conceptual level that spans wording differences and included constructs as well as domains. To our knowledge, no prior study of dimensionality has included multi-item measures of as many constructs as were included here.

Analytic approach. To study the relationships among the trust-relevant constructs reviewed above, the studies reported here used a consistent analytic strategy.

Preliminary Analyses. Prior to conducting our primary analyses we evaluated the patterns of missing data in each study. Totals of $79 \%, 77 \%, 87 \%$, and $99 \%$ of the respective Study 1, 2, 3, 4 samples had complete data on the trust items. In Studies 1 and 3, a total of 9 of $702(1 \%)$ and 23 of $645(4 \%)$ (respectively) individuals were missing all data on the trust variables and so were excluded from the analyses. Next, for each of the studies, ordinal regressions were conducted predicting the number of questions on which each participant had missing data using the averages across items assigned to each construct and demographics (e.g., gender, race, education). For Studies 1-3, each of these models accounted for non-significant variance in the missingness variable and so our data were assumed missing at random, and appropriate for our analyses (i.e., participants missing data on only some items were retained). In

\footnotetext{
${ }^{4}$ For comparability, the present analysis includes only constructs that were used in at least two of the four studies.
} 
Study 4 however, modest trends suggested that individual differences in perceived bias and honesty as well as identifying as non-White may related to participants' likelihood of having missing data. However, removing the six individuals with missing data (bringing the sample to $\mathrm{N}=393$ ) did not meaningfully alter model estimates. Thus, our conclusions are no different with or without these six individuals included.

Phase 1 analyses (a priori theory-driven models). Next, confirmatory factor models were estimated using the Maximum Likelihood-Robust estimator in Mplus v. 7.11 (Muthén \& Muthén, 2013). In these models, the items were entered as indicators of their hypothesized latent construct, latent factors were identified by setting the factor means to 0 and variances to 1 , and all latent factors were allowed to correlate freely.

Within each of our samples, we first tested the simplest one-factor "compact model" (John \& Benet-Martinez, 2000), which we used as a baseline model. Then, to the extent possible,${ }^{5}$ we tested the specific models depicted in Table 1 , using the specific items and constructs included in each study sample. The subsequently more complex models follow the theoretical distinctions made in our review. Most of the models are nested within each other. Specifically, model $2 \mathrm{~F}$ was nested within $3 \mathrm{~F}$ which was nested within $4 \mathrm{Fa}$, which was nested within $5 \mathrm{~F}$, which was nested within $6 \mathrm{~F}$, and all models were nested within our MF model, as illustrated in Figure 1. Model 4Fb (illustrated by the dotted circle in Fig. 1) is one model that does not fit neatly into the nesting pattern of all the others, but it is still nested within the MF model, and contains the $3 \mathrm{~F}$ and $2 \mathrm{~F}$ models nested within it. If the distinctions among the individual constructs are statistically important, we would expect that the MF model would be

\footnotetext{
${ }^{5}$ As previously mentioned, each study included a somewhat different set of constructs. Also, Study 4 did not include dispositional, direct/unspecified, or loyal trust, and therefore was only able to focus on the dimensionality of the trustworthiness constructs. To distinguish Study 4 models from those including a wider range of constructs, we use an adapted labeling system described later.
} 
the best-fitting model, and significantly better fitting than each of the nested models according to rescaled log-likelihood ratio tests. If the covariances in the data sets require fewer distinctions between constructs than are modeled in MF, then one or more of the simpler nested models may fit as well as the MF model. We used rescaled log-likelihood ratio tests for nested model comparisons.

To evaluate the fit of these confirmatory factor models we examined a number of indicators. We examined the chi-square test of exact fit; however, this index is particularly sensitive to model complexity, such that in complicated but non-saturated models, a significant test of deviation from exact fit is virtually guaranteed (Kline, 2005). We therefore examined alternative fit indices as well. Specifically, we examined the Root Mean Square Error of Approximation (RMSEA, or test of close fit), Tucker Lewis Index (TLI), Comparative Fit Index (CFI), and the Standardized Root Mean-Square Residual (SRMR) (Hu \& Bentler, 1999). Cutoffs for these indices generally fall between the following ranges with the first value being a more liberal indicator of sufficient or adequate fit (Browne \& Cudeck, 1993) and the second value being a more conservative indicator of good model fit (Hu \& Bentler, 1998): RMSEA < 0.10 or 0.06 ; CFI $>0.90$ or 0.95 ; TLI $>0.90$ or $0.95 ;$ SRMR $<0.08$ or 0.05 . We also examined Aikaike's Information Criterion (AIC; Akaike, 1987), and Bayesian Information Criterion (BIC; Schwarz, 1978). The AIC and BIC can be used to compare non-nested models (e.g., Models 4a and 4b) and smaller values indicate better fit (Schumacker \& Lomax, 2010).

Phase 2 analyses (post hoc exploratory models). After testing for the simplest and best fitting a priori model in Phase 1 analyses, we investigated additional models suggested by the results. When the MF model was the best-fitting model, we were particularly interested in whether the data might still suggest ways of reducing the many factors (either by collapsing 
certain factors, or by adding a higher-order factor) that we had not hypothesized based on our $a$ priori theoretical analysis. Therefore, for each best-fitting model, we examined indicators of local fit and misfit (e.g., the normalized residual covariance matrix and modification indices), as well as examining correlations among the latent variables. Correlations above |.80-.90| indicate that two variables share more than $65-80 \%$ of their variance and suggest poor discriminant validity and possible model over-parameterization. This may indicate that certain factors might be collapsed, or that, although the constructs are relatively distinct, they nonetheless form a higher-order factor (John \& Benet-Martinez, 2000). When warranted, we also used exploratory factor analyses of the latent factor scores as a tool to clarify the patterns of correlations between the MF estimated factors. ${ }^{6}$ Whenever the data suggested strong relationships between two or more latent factors, we attempted to compare the fit of post hoc models that collapsed the items into one factor with those that instead added one or more higher-order latent factors.

We next describe each study and present its specific results. Studies are ordered in terms of sample scope (from most narrow to most broad), with Study 1 focused on students at a university and their perceptions of police, Study 2 on residents of a city and their perceptions of local government, Study 3 on a statewide sample of landowners and their perceptions of a natural resource regulatory institution, and Study 4 on a national sample of Americans and their perceptions of their state governments. We hold discussion until the end in order to emphasize the patterns of findings across studies.

\section{Study 1}

\section{College Student Perceptions of the Police}

\footnotetext{
${ }^{6}$ Whenever we conducted exploratory analyses, we conducted them in multiple ways (e.g., using principal axis factoring (PAF) and principal components analysis (PCA), based on both correlations and covariances, and using Varimax and Promax rotations) and then report the most common grouping of constructs.
} 
Study 1 was designed to assess trust in police among college students. Trust is important in this context because policing and public safety rest upon the voluntary compliance of citizens (Tyler \& Fagan, 2008; Tyler \& Huo, 2002) and trust in police — or a lack thereof — can have considerable impacts upon police-citizen relations where stark power differentials exist. Indeed, this phenomenon has been clearly illustrated in the Detroit riots in the 1960s, the L.A. Rodney King riots in the 1990s, and most recently in events in Ferguson, Missouri, and in other places throughout the U.S.

\section{Participants}

Participants were 702 students at the University of Nebraska-Lincoln (UNL), and were $62 \%$ female, $78 \%$ White (non-Hispanic), leaned Republican in their political affiliation $($ Democrat $=18 \%$, Republican $=37 \%$, no affiliation/other $=41 \%$, not reported $=4 \%)$, and had an average age of 18.8 years $(S D=1.63)$.

\section{Procedures and Measures}

Participants were recruited to complete the UNL psychology department's mass testing in 2013. They completed all measures, including those for this study, via an online survey that was available for approximately 1-2 weeks at the beginning of the semester. Participants received course credit for their participation. Analyses reported here focus on a measure of trust in the Lincoln (NE) Police Department which included items assessing all 12 of our constructs: dispositional trust; direct/unspecified and loyal trust; and the trustworthiness constructs of care, competence, honesty, shared values, fairness, bias, voice, legitimacy, and cynical beliefs. Specific items assessing each construct are listed in Table 4.

[Insert Tables 3, 4, 5 about here] 


\section{Results}

Phase 1 (a priori). Comparison of nested models found that the MF model fit significantly better than each of the nested models according to rescaled log-likelihood ratio tests (see Table 3). ${ }^{7}$ As shown in Table 3, the best fitting model was the MF model. It fit reasonably well to the data according to the alternative fit indices, with all of them meeting more liberal recommended cut-offs for sufficient fit, but only RMSEA meeting the more stringent cut-off: $\mathrm{CFI}=.94 ; \mathrm{TLI}=.93 ; \mathrm{RMSEA}=.05 ; \mathrm{SRMR}=.06$. The test of exact fit was also significant $\left(x^{2}(440)=1050.72, p<.001\right)$, indicating imperfect fit. Importantly, however, the MF model identified seven estimated correlations between factors greater than 1, resulting in a non-positive definite (and thus non-invertible) PSI matrix, rendering the resulting parameter estimates potentially inaccurate. Model 6F similarly resulted in a non-positive definite PSI matrix. Of the remaining models, the best fitting model was model $4 \mathrm{Fb}$, which did not achieve exact fit $\left(\mathrm{x}^{2}(440)\right.$ $=1050.72, p<.001)$, but did achieve adequate fit according to the alternative indices $(\mathrm{CFI}=.92$, $\mathrm{TLI}=.91, \mathrm{RMSEA}=.07, \mathrm{SRMR}=.07)$. The $4 \mathrm{Fb}$ model also estimated all items as significantly loading on the indicated factors (see Table 4).

Phase 2 (post hoc). Although examination of the normalized residuals for inter-item covariances did not seem to reveal a consistent pattern of local misfit, examination of the correlations among factors estimated by model $4 \mathrm{Fb}$ (see Table 5) revealed a very high correlation $(r=.99)$ between the trust factor including the direct/unspecified and loyal trust items, and the positive trustworthiness factor. Given these results, we examined a post hoc three-factor model $(\mathrm{PH}-3 \mathrm{~F})$ that collapsed the trust and positive trustworthiness factors, identifying one factor with all of the items from the direct/unspecified and loyal trust constructs and positive trustworthiness

\footnotetext{
${ }^{7}$ In addition, although not reported in Table 1, each successively nested model improved fit to the data according to the same rescaled log-likelihood ratio comparisons. Full results available from the corresponding author.
} 
constructs, while leaving one factor identified by items from dispositional trust, and one identified by items from the negative trustworthiness constructs. This model fit only slightly (but still significantly) worse than the nested model $4 \mathrm{Fb}$, (absolute value $-2 \Delta \operatorname{LL}(3)=9.88, p=.020$ ), and its alternative fit indices were very close to those obtained for $4 \mathrm{Fb}$. Consistent with the analytic strategy applied to the other studies, we also attempted to examine a parallel model in which, instead of collapsing the factors, we added a higher-order factor indicated by trust and positive trustworthiness latent factors. However, this model would not converge and thus could not be evaluated.

\section{Study 2}

\section{Resident Perceptions of Local Public Officials}

Study 2 was conducted within a public engagement effort with the City of Lincoln, Nebraska. Beginning in 2008, the mayor's office actively sought to engage the public in its budgeting and spending prioritization efforts (Herian, Hamm, Tomkins, \& PytlikZillig, 2012; PytlikZillig, Tomkins, Herian, Hamm, \& Abdel-Monem, 2012; PytlikZillig, Tomkins, et al., 2011). Questions regarding trust were included in this project in order to understand the public's trust in local government and how it might be related to specific city spending priorities.

\section{Participants}

Although the survey containing the trust items was partially completed by 2,734 participants, only a subset of 1,033 participants went on to complete an optional part of the survey which contained many of the questions for the present research, and only 890 completed the trust items in that optional part of the survey. We focus our analyses on these 890 . These participants were largely representative of the Lincoln population generally and were slightly more than half male (58\%; Lincoln population 50\%), mostly White (95\%; Lincoln population 
$89 \%)$, and most had completed a bachelor's degree or higher (69\%).

\section{Procedures and Measures}

The data reported here were taken from an online survey hosted on Qualtrics.com. The survey was open to city residents for six weeks during the spring/summer of 2011, and citizens were recruited to participate via the city's website, press releases, and media publicity. No compensation was offered for participation; however, participants were informed that their responses would be summarized in a public report that would be read by city officials (PytlikZillig, Abdel-Monem, Herian, Williams, \& Tomkins, 2011). The online survey included measures of 11 trust-relevant constructs (all of those in Study 1 except perceived bias): dispositional trust; direct/unspecified and loyal trust; and the trustworthiness constructs of competence, legitimacy, shared values, cynical beliefs, care, voice, honesty, and fairness. Items assessing each construct are listed in Table 7.

[Insert Tables 6, 7, 8 about here]

\section{Results}

Results from this study indicated, once again, each successive nested model improved fit to the data. As shown in Table 6, the best-fitting model was the MF model, which fit significantly better than each of the nested models according to rescaled log-likelihood ratio model comparisons. Although exact fit failed to hold for the MF model $\left(x^{2}(379)=642.86, p<\right.$ $.001)$, evaluation of the alternative fit indices revealed good fit of the model to the data, with all indices achieving stringent cut-offs $(\mathrm{CFI}=.96 ; \mathrm{TLI}=.96 ; \mathrm{SRMR}=.04 ; \mathrm{RMSEA}=.04)$. All of the items also loaded significantly on their proposed factors (see Table 7 for item loadings).

Phase 2 (post hoc). Evaluation of the correlations among the latent constructs (see Table 8) revealed most of the latent constructs were highly correlated (most $r s>|.80|$ ). Dispositional 
trust was, as expected, much less related to the other constructs $(r s<|.55|)$. The only negative construct included (i.e., cynical beliefs) was slightly less related to the other constructs $(r s=-.76$ to -.87 , excluding a -.40 correlation with dispositional trust). Legitimacy also appeared to correlate somewhat less with other factors (of the five correlations between institutional trust constructs that were less than |.80|, three were with legitimacy).

Evaluation of local sources of misfit and modification indices suggested many itemfactor cross loadings might improve the model. Furthermore, exploratory factor analyses of the latent factor scores based on the MF model suggested that all constructs formed a single factor. When two factors were extracted and rotated, all latent factors loaded on a single factor except for dispositional trust, which loaded on its own factor.

Given these exploratory results and the excessive covariance among factors, one might expect good fit of a two factor model separating dispositional trust items from all other institutional trust items on two latent factors. However, this is the $2 \mathrm{~F}$ model, which clearly fits significantly worse than the MF (see Table 6). We also tested a higher-order model in which all of the institutional trust latent variables indicated a higher-order factor (PH-HO1). Although the rescaled likelihood ratio test indicated that this model fit significantly worse than the MF model (Table 6), the fit indices suggested adequate fit, and much better fit than the $2 \mathrm{~F}$ (collapsed factor) model.

\section{Study 3}

\section{Landowner Perceptions of Natural Resource Managers ${ }^{8}$}

Study 3 evaluated the dimensionality of and relationships between the trust constructs in a statewide study of Nebraska land owners' attitudes toward the Nebraska Game and Parks

\footnotetext{
${ }^{8}$ Note that a subset of the constructs evaluated here have been reported elsewhere (Hamm, 2014; Hamm, Hoffman, Bornstein, \& Tomkins, in press).
} 
Commission, an institution responsible for the management of Nebraska's natural resources. In the state of Nebraska, more than $95 \%$ of the state's land area is privately owned, and natural resource management institutions often cannot require compliance on private property. We investigated trust in this context because trust and its related constructs have consistently been argued and shown to be an effective motivator of cooperation and compliance by researchers across domains (De Cremer \& Tyler, 2005; Hamm, PytlikZillig, Herian, Tomkins, et al., 2013; May, 2004; Ostrom, 1998).

\section{Participants}

This survey involved Nebraskans owning more than 20 acres of rural land. A total of 1,716 land owners were selected randomly to receive the mail survey, and 645 land owners responded to the survey (response rate $=38 \%$ ). Participants were mostly male $(77 \%)$, White (96\%), and owned more than 100 acres (72\%). Consistent with Nebraska demographics, the sample tended to lean Republican (47\%; an additional 12\% indicated that they were independent but leaned Republican) and politically conservative (38\%).

\section{Procedures and Measures}

This survey took place from approximately June to August of 2013, via a mail survey conducted by the University of Nebraska-Lincoln Bureau of Sociological Research, and only included Nebraskan landowners. With the first mailing of the survey, participants received a $\$ 1$ cash incentive and a business reply envelope. Ten days after the first mailing, participants received a reminder postcard. Ten days after the reminder post card, those not yet responding received a second survey but no additional incentive. The survey included 34 items assessing 10 trust-relevant constructs (all except loyal trust and honesty): dispositional trust; direct/unspecified trust; and trustworthiness constructs of competence, legitimacy, shared values, 
cynical beliefs, care, voice, fairness, and bias (see Table 10 for wording of items assessing each construct).

[Insert Tables 9, 10, 11 about here]

\section{Results}

Phase 1 (a priori). Results from all models tested are listed in Table 9. Comparison of nested models found each successive model improved fit to the data according to rescaled loglikelihood ratio comparisons. The best fitting model (and the only model to achieve thresholds of adequate fit across all indicators) was the MF model. Again, exact fit failed to hold, even for the MF model $\left(x^{2}(482)=1240.77, p=<.001\right)$, but the alternative fit indices revealed reasonable fit to the data $(\mathrm{CFI}=.94 ; \mathrm{TLI}=.93 ; \mathrm{SRMR}=.04 ; \mathrm{RMSEA}=.05, p=.54)$, with all four alternative fit indices exceeding the liberal recommended cut-offs, and two meeting or exceeding the more stringent cut-offs. For the MF model, analyses also revealed significant loadings for all indicators on their hypothesized factors (see Table 10).

Phase 2 (post hoc). Evaluation of the correlations among the 10 latent constructs from the MF model (Table 11) found care, competence, direct/unspecified trust, legitimacy, procedural fairness, shared values, and voice were correlated at $r s>.80$, indicating that they shared the majority of their variance (> 60-80\%). In contrast, the negative constructs (bias and cynical beliefs) were highly correlated with each other $(r=.80)$, but were less correlated with the positive constructs (other $r$ s involving cynical beliefs $<.75$, involving bias $<.60$ ), and dispositional trust was much less correlated with all other constructs (all $r s \leq .16$ ). Evaluation of local sources of misfit and modification indices also tended to suggest that certain negative items were more correlated than expected, and sources of misfit also tended to suggest relationships among positive items. Furthermore, exploratory factor analyses of the factor scores based on the 
MF model suggested a split between positive and negative institutional trust constructs. That is, competence, legitimacy, fairness, care, unspecified trust, shared values, and voice loaded on one factor; bias and cynical beliefs loaded on a second factor; and dispositional trust loaded on its own factor.

Based on the exploratory factor analyses as well as the high covariance among the seven positive institution-specific constructs and moderately high covariance between the two negative institution-specific constructs, we also tested the following post hoc models: a three-factor model in which dispositional trust items, all items for positive constructs (including direct/unspecified trust items), and all items for negative constructs loaded on separate factors (PH-3F); a fourfactor model in which dispositional trust items, positive construct items (including direct/unspecified trust items), cynical beliefs items, and bias items loaded on separate factors (PH-4F); and two parallel models in which (instead of collapsing factors) higher-order factors were added to the MF model. Specifically, one model added a single higher-order factor indicated by the positive latent factors ( $\mathrm{PH}-\mathrm{HO} 1)$, and one added two higher-order factors, one indicated by the positive latent factors and one indicated by the negative latent factors (PHHO2). Of these, the higher-order-factor models tended to fit better than the collapsed factor models, and the best-fitting post hoc model based on examination of AIC and BIC values was PH-HO1. However this model still had a relatively high SRMR (.14). Each of the post hoc models fit also significantly worse than the MF model based on nested model comparisons conducted using a rescaled likelihood ratio tests $(-2 \Delta \mathrm{LLs}>355, d f \mathrm{~s}=33-42, p \mathrm{~s}<.05)$.

\section{Study 4}

\section{Americans' Perceptions of Their State Government}

Study 4 focused on American adults' trust in their state governments. The data reported 
here were collected through an online survey hosted on Qualtrics.com and made available to participants via Amazon Mechanical Turk (MTurk). MTurk is a crowd-sourcing Internet marketplace increasingly used by social science researchers to collect data (Berinsky, Huber, \& Lenz, 2012; Buhrmester, Kwang, \& Gosling, 2011; Mason \& Suri, 2012).

\section{Participants}

Participants were 399 American adults who were $42 \%$ female, $72 \%$ White, $8 \%$ Asian American, 8\% African American, 1\% Native American, and 4\% Hispanic. Seven percent of participants identified with more than one of these ethnic groups. The sample leaned Democratic and independent in their political affiliation (Democrat $=33 \%$, Republican $=13 \%$, independent/no affiliation/other $=54 \%$ ) and about half of participants had completed a bachelor's degree or higher (48\%).

\section{Procedures and Measures}

Participants were recruited to complete an online study through MTurk for \$0.15 during November 2013-January 2014. Participants were assigned to different textual descriptions of an ostensible ballot initiative in their state (being informed later that the initiative was only hypothetical), and reported their thoughts in response to what they had read. Following this, participants responded to a number of measures. Analyses reported here focus on a measure of trustworthiness of their state government which included items assessing the nine trustworthiness constructs of competence, legitimacy, shared values, cynical beliefs, care, voice, honesty, fairness, and bias. Specific items used to assess these constructs are listed in Table 13. This study differed from the other studies in that it included only items assessing trustworthiness constructs, did not include the dispositional trust and trust (direct/unspecified trust and loyal trust) factors, and the trustee target varied among participants from different states (as they focused on their 
own, not a common, state government).

[Insert Tables 12, 13, 14 about here]

\section{Results}

Phase 1 (a priori). Once again, comparison of nested models found that each successive model improved fit to the data according to rescaled log-likelihood ratio comparisons. As shown in Table 10, the best fitting model was again the many factor model (we label this TW-MF, to indicate that it is the MF of trustworthiness constructs only). The TW-MF model fit reasonably well to the data, and considerably better than any of the alternative models, with all of the alternative fit indices meeting more liberal recommended cut-offs for sufficient fit, and both RMSEA and SRMR meeting the more stringent cut-offs: CFI = .94; TLI = .93; RMSEA = .06; SRMR $=.05$. The test of exact fit was still significant $\left(\mathrm{x}^{2}(341)=762.790, p<.001\right)$, indicating imperfect fit of the model to the data. The TW-MF model also left all items significant on their hypothesized factors (see Table 13).

Phase 2 (post hoc). Examination of the TW-MF model correlations between latent factors (see Table 14) revealed only three correlations above |.80|. Voice correlated highly with both legitimacy $(r=.87)$ and fairness $(r=.90)$, and fairness and legitimacy also correlated highly with one another $(r=.87)$. Meanwhile, 11 correlations were $<|.60|$, and 8 of these involved the negative constructs (perceived bias and cynical beliefs about the institution) correlating with positive constructs. Exploratory factor analyses of the factor scores derived from the TW-MF model supported these findings, as legitimacy, fairness and voice consistently loaded on the same factor across numerous extraction and rotation procedures. Cynical beliefs and perceived bias also consistently loaded on the same factor.

Based on these exploratory results, we tested the fit of post hoc models that either 
collapsed the negative construct items onto a single factor (PH-TW-8F), or collapsed the legitimacy, voice, and fairness items onto a single factor (PH-TW-7F), or incorporated both types of collapsing (PH-TW-6F). We also tested parallel higher-order factor models that either contained a higher-order factor indicated by the cynical beliefs and perceived bias latent factors (PH-TW-1HOa), or a higher-order factor indicated by the legitimacy, voice, and fairness latent factors (PH-TW-1HOb), or included both higher-order factors (PH-TW-2HO). As shown in the bottom part of Table 12, the higher-order models fit adequately to the data and fit not significantly worse than the TW-MF model. However, the collapsed factors models each fit significantly worse than the TW-MF model.

\section{Discussion}

In response to McEvily and Tortoriello's (2011) assessment that more research is needed to determine the dimensionality of trust-relevant constructs under different conditions, the present research evaluated the relations among comparatively large subsets of trust-relevant constructs in notably distinct contexts: college students' trust in the police, a local public's trust in city government, landowners' trust in a natural resource management institution, and American's trust in their state government. Across the four samples and contexts investigated, there were a number of common findings, as well as a number of divergences.

\section{Common Findings across Contexts}

First, all studies converged on the finding that, of the models without higher-order factors, the many factor model was the a priori model that best represented the data. Although, in Study 1, the correlations between positive factors in the MF model were so high as to disrupt model computation, assigning all positive items to a single factor still did not result in as good fit as the MF model, suggesting that participants in the student sample were still making some 
distinctions among the constructs. Furthermore, across studies, tests of post hoc models generally revealed that adding higher-order factors resulted in better fit than collapsing factors. These findings suggest that the individual constructs we assessed are distinguishable to different groups of participants and across contexts. The theoretical implication of this is simply that the different types of items, chosen to represent different trust-relevant constructs, are not equivalent. Thus, although as previously noted the Mayer et al. (1995) model may have included identification (shared values) as part of their idea of integrity, people do distinguish between items assessing similar but not identical constructs (e.g., shared values versus honesty).

These results also suggest that the items we used, although they varied somewhat across studies, seemed to adequately target the hypothesized latent constructs. This is supported both by the high loadings of items on their assigned factors, and by the adequate-to-high reliabilities reported in Tables 5, 8, 11, and 14. A closer look at the standardized factor loadings estimated for the items in the best-fitting a priori model (without errors) obtained in each study reveals that most loadings are above .7, indicating that most items share approximately $50 \%$ or more of their variance with their assigned factors. There was also some consistency across the items with lower loadings. For example, “I trust what most people say” was used to assess dispositional trust in both the local governance and police contexts, and had a $<.7$ loading on its factor in both contexts. Also, the legitimacy item "the procedures followed by [institution] are lawful" was used in the state and local governance contexts and police context, and in each context either had the lowest loading of all the legitimacy items, or a loading <.7. Similarly, the voice item relating to people being able to "influence" institutions (and not just be heard or listened to), was consistently among the lowest loading items on the voice factor. Thus, in addition providing evidence of the separability of the trust-relevant factors we investigated, the results provide 
information useful for future development of cross-context measures of the specific constructs.

A second consistent finding was that the many factor CFA models estimated very high or relatively high correlations between the trust/trustworthiness latent factors, but lower correlations with dispositional trust. This confirms prior research identifying dispositional trust as a correlated but separate construct from specific trust toward a target (Rousseau et al., 1998). Thus, there is evidence of high discriminant validity for dispositional versus unspecified and loyal institutional trust and trustworthiness measures, but lower discriminant validity among various trust and trustworthiness measures - especially among those that are positively valenced. When trust per se is operationalized with items such as those used to assess direct/unspecified or loyal trust, it may not be well discriminated from positive trustworthiness, despite the theoretical distinction. In the police context, the positive trust/trustworthiness factors were especially highly correlated. ${ }^{9}$ In practical terms, the high correlations between the positive factors means that assessing any one of the factors provides a fair estimate of where each respondent is likely to fall on any of the other positive constructs, relative to other respondents. Furthermore, regression analyses using multiple positive constructs as predictors could prevent any of the predictors from being significant, due to high multicollinearity. Future research should examine the statistical distinctiveness of alternative measures such as those that directly assess willingness to support, give control to, or otherwise be vulnerable to the institution.

It is important to stress that, in Studies 1-3, there was a single trustee target that participants evaluated. Thus, the high correlations we found among many of the latent factors do not preclude the possibility that some participants may have conflicting perceptions of the

\footnotetext{
${ }^{9}$ It is possible that our student sample, receiving course credit for completing the measures, but perhaps not as interested in expressing their trust-relevant views as our volunteer samples the other studies, were less attentive in their consideration of the different constructs being assessed. However, the quality of the data is supported by the fact that it did result in distinct factors for dispositional trust and for the negative constructs of bias and cynicism.
} 
institution's specific forms of trustworthiness-e.g., viewing it as caring but not competent, or honest but also biased. It is theoretically possible to feel that the individuals in a given institution are competent but do not care about the public, or that the institution shares the values of the participant but does not treat the public fairly. In fact, comparison of mean ratings of items representing different trust-related constructs did find different "trust-relevant construct profiles" across our four studies. For example, the landowners viewed the natural resource regulators as significantly more likely to share their values $(M=4.58, S D=1.21$, on a 1-7 scale) than as giving the public a voice in their decisions $(M=4.24, S D=1.14), t(597)=9.14, p<.001$; while the reverse was true for the local residents' perception of city officials - residents viewed the city government officials as significantly higher on voice $(M=3.77, S D=1.11$, on a 1-6 scale) than on shared values $(M=3.60, S D=1.16), t(887)=6.62, p<.001$.

However, the methods used here (i.e., factor analyses focusing on one institution at a time, and at a single point in time) would not result in different factor dimensions unless many people vary (i.e., disagree) in their perceptions of the relative relationships of these different constructs for the target of trust. For example, suppose that people vary widely in their trust of a particular institution, but do not vary in their relative ranking of how competent it is versus how caring it is (perhaps most agree it is a lot more caring than competent, but trusting persons rank the institution higher on both dimensions). In this case, use of factor analytic procedures will not be able to distinguish between competence and care, even though the institution is quite different on the two dimensions, because all respondents are focused on the same target, and in agreement on the relative ranking of its characteristics. For factor analyses to identify different dimensions there needs to be adequate variation. When all respondents are focused on one target at one time point, all the variation comes from differences in the perceptions of the respondents, with little 
variation from the target.

To address this concern, a better indicator of the full dimensionality of trust constructs across institutional domains would include widely varying institutional targets as well as respondents. ${ }^{10}$ Nonetheless, the results from these studies are meaningful because people could have varied widely in their relative endorsement of different constructs (e.g., with some people reporting that the institution shared their values but that they felt they were low in competence, and others saying quite the reverse). However, this did not happen very often, as indicated by the very high correlations between positive factors. Thus, the present studies do provide evidence of an important finding: Across most of our contexts (with Study 4 providing somewhat of an exception, perhaps because in that study the targeted trustees did vary between states), very different groups of respondents, and somewhat varied constructs and items, variations in people's perceptions of the institution appear to be global (ranging from high to low) rather than specific (i.e., varying in whether their positive impressions are based differentially on, say, specific constructs of integrity vs. competence). It is thus possible that, instead of carrying around with them highly detailed notions about different trust-relevant evaluations of an institution that may vary on numerous dimensions, oftentimes people may instead carry with them general impressions about the institution's positive and negative characteristics that then have main effects upon their more specific ratings. Although the higher order factors tested here provide some support for this possibility, future research is needed to test it directly.

A third common finding was that somewhat lower correlations tended to exist between the positive trust/trustworthiness constructs (assessed with mostly positively worded items), and

\footnotetext{
${ }^{10}$ It also may be noteworthy that the respondents in three of our studies were from a single state (Nebraska), which could limit generalizability. However, there was substantial diversity across the three samples (students, rural landowners, citizens of a mid-sized city), and Study 4 included a national sample.
} 
the negative constructs (assessed with mostly negatively worded items). Overall, our results appeared to be more consistent with Poortinga and Pidgeon's (2003) finding of one general positive trustworthiness factor and one negative and cynical factor (see also Frewer, Howard, Hedderley, \& Shepherd, 1996), than with others' findings of distinctions among moral-relational perceptions (e.g., including care and integrity) versus more performance-calculative factors (e.g., reflecting ability) (Jungermann et al., 1996; Metlay, 1999; Rousseau et al., 1998). For three of the four samples, the model that split trustworthiness constructs into positive and negative types fit better (according to AIC and BIC non-nested comparison indices) than a model with the same degrees of freedom, but using an ability/warmth topical split. This finding is consistent with prior theorizing that trust and distrust are distinct and separable constructs (Cook \& Gronke, 2005; Van De Walle \& Six, 2013). Alternatively, however, the separation of positive and negative items could reflect a measurement artifact, much in the way that a "difficulty" factor sometimes emerges, not because items vary in content but because they differ in likelihood of endorsement (Saxe \& Weitz, 1982). Relatedly, acquiescence bias may affect the separability of positively worded (trust) items from negatively worded (distrust) items (McClendon, 1991; Watson, 1992). In other words, a common propensity to agree with items regardless of their content may lower the correspondence between negatively and positively worded items.

Our studies, importantly, did confound positive and negative constructs with item wording. That is, cynical beliefs and bias were the only constructs assessed with primarily negatively-worded items. A better test as to whether the distinguished factors were due to wording in a positive or negative direction (method variance) versus differences between constructs (e.g., cynical beliefs and perceived bias on the one hand and generally positive perceptions of trustworthiness on the other) would be if there had been both positive and 
negative items assessing each positive and negative construct (McClendon, 1991; Watson, 1992). Future research should test the possibility that any negatively worded item (e.g., items assessing "lack of" competence or care) might load with cynical beliefs and bias or whether they still fit better with their topical construct.

A final consistent finding across studies was the construct most related to unspecified trust. Although we did not measure "willingness to support" in the current research, measures of unspecified trust are common, especially in public opinion surveys like the GSS, ESS, and ANES. In these surveys, unspecified trust is taken to be a general assessment of trust in the target institution (often government) so an understanding of the other trust-related constructs that are most related to it is important. Although unspecified trust was only measured in Studies 1, 2, and 3 , in all three analyses, care was the trust-related construct that was most related to unspecified trust (in Study 1, care was included in the positive trustworthiness factor). This suggests that care may be especially important for trust across contexts.

\section{Divergences across Contexts}

When comparing the a priori lower-order factor models, some differences did emerge between studies. For example, the ability-warmth split for trustworthiness constructs appeared more valid than the positive-negative split within the local governance context than in other contexts. This finding, however, may be due to having only one negative construct in that study. In addition, the estimated correlations among latent factors varied across studies. For example, estimated correlations among latent constructs resulted in 12 inter-factor correlations above .9 among city residents in Study 2, but more moderate (only 3 correlations above .8) correlations among factors for the American adult sample in Study 4. While this could suggest that diversity of respondents (city residents versus a broader sample of American adults) can impact 
measurement factor structures, it may instead suggest that correlations among factors will be smaller if the targeted trustees are more varied. That is, only in Study 4 did respondents focus on different trustees (their own state government, which varied dependent upon the participant's state residence).

Another difference among studies was that although the high correlations among factors suggested that some factors might be collapsed or used to indicate higher-order factors, the best alternative (and simplified) measurement solution varied by study, suggesting somewhat different measurement models across contexts. ${ }^{11}$ As previously noted, most of the studies were suggestive of the utility of having higher-order factors for positive (and sometimes also for negative) constructs. However, Study 4 (state governance context) differed in that there also was evidence that legitimacy, voice and fairness were more closely related to each other than to the other institutional trust/trustworthiness constructs. In the local governance context (Study 2), legitimacy also showed somewhat lower correlations with other constructs, but did not correlate particularly more highly with voice and fairness. Also, there was no evidence of a "higher-order legitimacy factor" in the police and natural resources contexts. The state governance context (Study 4) was the only context in which some of the post hoc models (specifically, those that included higher-order factors, including a higher-order factor for legitimacy, voice, and fairness) fit as well as the many-factor model.

Future research is needed to better understand why the structure of trust-relevant constructs might differ across contexts and samples. As previously noted, separability of constructs might vary due to factors such as the extent to which variation exists among respondents and/or the trustee targets. Among respondents, variations in knowledge of and

\footnotetext{
${ }^{11}$ We did not conduct a formal test of factor equivalence across studies because of the use of different items, response scales, and inclusion of different constructs across studies.
} 
experience with the trustee may allow some factors to separate from others, especially such knowledge and experience allows for people to form diverse perceptions of the trustee and to distinguish bases of their trust. Separability may also result for other reasons; for instance, directional motivated reasoning (Kunda, 1990) may compel an individual to perceive institutional trustworthiness differentially across constructs in order to compensate for a specific psychological threat. Shepherd and Kay (2012) found that experimentally-induced feelings of low comprehension of energy sources motivated individuals to report greater trust in federal agencies to manage the sources and to deal with issues that are associated with them. Essentially, individuals compensated for not trusting themselves to understand the sociopolitical issues related to energy technologies by trusting more in institutions. It may not be the case, however, that low comprehension encourages boosts in all trust-relevant constructs. In other words, some trust-relevant constructs may be unrelated to the motivated reasoning related to specific psychological threats, ultimately leading to differentiation among constructs.

\section{Implications}

Although we do not claim our findings are the last word on the dimensionality of trustrelevant constructs (in fact, we argue against such a view, given that there are many more possible contexts and participant samples to study), they may have important implications for understanding trust attitudes when measured toward a specific institution at a given point in time. The practical implications of these findings are that, if one is only interested in estimating the relative amount of trust that someone has in a specific institution, at a specific point in time, it is probably not necessary to assess 38,12 , or even 3 different constructs. If one knows a given person's response to one of the positive institution-specific trust/trustworthiness constructs, then one can fairly accurately predict how he/she will respond to the other positive constructs, relative 
to other people completing the same scales. However, it could add additional information to ask explicitly about people's cynical beliefs and other negative perceptions, as negative perceptions may be somewhat distinct from positive ones. Asking questions about one's disposition to trust will also add information because, as expected, dispositional trust nearly always shared an estimated less than $25 \%$ of its variance with other target-specific trust-relevant constructs (most $r s<.50)$.

On the other hand, even when researchers or practitioners are focused on one institution at one time point, they may have good reasons for wanting to assess narrower, more specific constructs. One reason might be diagnostic. If an institution wishes to improve public trust, it could be useful to know if most people already find it high in integrity but lower in competence, because this specific knowledge would then inform the specific reforms or public education that the institution employs. Alternatively, different situations may suggest the importance of different constructs. If an institution has been recently attacked by the media for a lack of competence, it may wish to assess impacts on the public's perception of its competence. Likewise, outcomes of interest to the police are different from those of interest for individuals involved in natural resource management — and such outcomes may be differentially predicted by various trust-relevant constructs. While our results suggest that direct and unspecified trust assessments are consistently most strongly related to care across contexts, other important outcomes (e.g., compliance with a difficult regulation or voluntary cooperation) may be best predicted by other constructs. For example, prior research suggests that judgements of process fairness may be especially predictive of compliance intentions in situations involving conflicting information (Hamm, PytlikZillig, Herian, Tomkins, et al., 2013). Additional research, however, is needed to ascertain which trust-relevant constructs will be important for varied outcomes. 
Finally, another reason to assess narrow trust-relevant constructs might be because one hypothesizes close causal relationships between constructs (e.g., see Colquitt et al.'s (2001) examination of the relationships between justice and trust constructs over time). When constructs are strongly causally related, measuring both constructs and submitting them to a factor analysis would result in both loading on the same factor. This does not mean they are not separate constructs, only that they are highly correlated due to their causal relations.

\section{Conclusion}

The present studies take a modest but important step toward filling the gap of extant research on the dimensionality of trust-relevant constructs. Unlike prior studies of trust in a single domain, the present studies include measures of relatively large numbers of trust-relevant constructs, each assessed with multiple item indicators in four different domains. We also extend prior work by including evaluations of legitimacy, loyal trust, and procedural justice constructs (such as voice, fairness, and bias), in addition to oft-cited constructs such as benevolence, integrity, competence, and shared values. Our findings include some results that were strikingly consistent across studies, and some that differed. The practical implications of our finding consistently high correlations between many of the constructs is that, if the goal is to identify respondents with relatively high or low trust, then measuring all of the potential trust-related constructs is unnecessary. Our results suggest that dispositional, positively-valenced, and negatively-valenced trust-relevant constructs are most likely to account for independent variance and may be worth assessing under such conditions. On the other hand, the practical implication of our consistent finding of the separability of the many-factors is that, if the goal is to diagnose public perceptions of an institution's specific areas of trustworthiness and distrustworthiness, then it is likely that the public will be able to make such distinctions, and the items used in these 
studies may be useful for making such diagnoses.

Nonetheless, our studies are not without limitations, and these limitations suggest directions for future research. For example, each of our studies focuses on one institution or one type of institution. Different factor structures may emerge if institutions are varied in addition to respondents within a single study. Furthermore, our studies only focus on institutional trust (i.e., trust in a specific institution). Different results are possible if instead the focus were on other types of trust, such as inter-organizational or interpersonal trust. Relatedly, our measures focus only on institutional trust, and our multi-item scales are composed of relatively few items. Although our scales resulted in adequate to good reliability estimates, it is not certain these will hold across all new contexts. Finally, our results may not generalize to institutions in Eastern nations such as China, Japan, and South Korea, or even Eastern European Nations like Bulgaria, Poland, and Hungary. Indeed, there is considerable evidence that institutional trust operates quite differently in Western and Eastern institutions (e.g., Cole \& Cohn, 2016; Inoguchi, Mikami, \& Fujii, 2007; Peng, 2014; Tan \& Tambyah, 2011). Such research, examined in conjunction with theoretical work aimed at fostering an integrated understanding of Eastern and Western properties of trust ( $\mathrm{Li}, 2008)$, and of the role of context for trust more generally (CamposCastillo et al., 2016), offers promising directions for trust research. Altogether, given that we only touched upon four contexts and samples out of potentially thousands, much work remains to understand when and why the factor structure of trust-relevant constructs may differ. Our studies and analyses, however, also offer tools - that is, samples of items assessing a number of trustrelevant constructs that worked relatively well across four contexts - that researchers can use to continue such work. 


\section{References}

Abramson, P. R., \& Finifter, A. W. (1981). On the meaning of political trust: New evidence from items introduced in 1978. American Journal of Political Science, 25, 297-307.

Akaike, H. (1987). Factor analysis and AIC. Psychometrika, 52(3), 317-332.

Bachmann, R. (2011). At the crossroads: Future directions in trust research. Journal of Trust Research, 1(2), 203-213.

Bales, R. F. (1999). Social interaction systems: Theory and measurement. New Brunswick, NJ: Transaction Press.

Bangerter, A. (2014). Investigating and rebuilding public trust in preparation for the next pandemic. European Psychologist, 19(1), 1-3.

Baumeister, R. F., \& Leary, M. R. (1995). The need to belong: Desire for interpersonal attachments as a fundamental human motivation. Psychological Bulletin, 117(3), 497529.

Berinsky, A. J., Huber, G. A., \& Lenz, G. S. (2012). Evaluating online labor markets for experimental research: Amazon. com's Mechanical Turk. Political analysis, 20(3), 351368.

Blader, S. L., \& Tyler, T. R. (2003). A four-component model of procedural justice: Defining the meaning of a "fair" process. Personality and Social Psychology Bulletin, 29(6), 747-758.

Boersma, M. F., Buckley, P. J., \& Ghauri, P. N. (2003). Trust in international joint venture relationships. Journal of Business Research, 56(12), 1031-1042.

Bornstein, B. H., \& Tomkins, A. J. (Eds.). (2015). Motivating cooperation and compliance with authority: The role of institutional trust. New York: Springer.

Brehm, J., \& Rahn, W. (1997). Individual-level evidence for the causes and consequences of social capital. American Journal of Political Science, 41, 999-1023.

Browne, M. W., \& Cudeck, R. (1993). Alternative ways of assessing model fit. In K. A. Bollen \& J. S. Long (Eds.), Testing structural equation models (pp. 136-163). Newbury Park, CA: Sage.

Buhrmester, M., Kwang, T., \& Gosling, S. D. (2011). Amazon's Mechanical Turk a new source of inexpensive, yet high-quality, data? Perspectives on Psychological Science, 6(1), 3-5.

Burke, K., \& Leben, S. (2007-2008). Procedural fairness: A key ingredient in public satisfaction. Court Review, 44, 4-25.

Campos-Castillo, C., Woodson, B. W., Theiss-Morse, E., Sacks, T., Fleig-Palmer, M. M., \& Peek, M. E. (2016). Examining the relationship between interpersonal and institutional trust in political and health care contexts. In E. Shockley, T. M. S. Neal, L. M. PytlikZillig, \& B. H. Bornstein (Eds.), Interdisciplinary perspectives on trust: Towards theoretical and methodological integration (pp. 99-115). New York: Springer.

Castaldo, S., Premazzi, K., \& Zerbini, F. (2010). The meaning (s) of trust. A content analysis on the diverse conceptualizations of trust in scholarly research on business relationships. Journal of Business Ethics, 96, 657-668.

Cen, G., \& Yu, J. (2014). Traditional Chinese philosophies and their perspectives on moral education. In L. Nucci, D. Narvaez, \& T. Krettanauer (Eds.), Handbook of moral and character education (2nd ed., pp. 30-42). New York: Routledge.

Cole, L. M., \& Cohn, E. S. (2016). Institutional trust across cultures: Its definitions, conceptualizations, and antecedents across Eastern and Western European Nations. In E. Shockley, T. M. S. Neal, L. M. PytlikZillig, \& B. H. Bornstein (Eds.), Interdisciplinary 
perspectives on trust: Towards theoretical and methodological integration (pp. 157-176). New York: Springer.

Colquitt, J. A. (2001). On the dimensionality of organizational justice: a construct validation of a measure. Journal of Applied Psychology, 86, 386-400.

Colquitt, J. A., \& Rodell, J. B. (2011). Justice, trust, and trustworthiness: A longitudinal analysis integrating three theoretical perspectives. Academy of Management Journal, 54, 11831206.

Colquitt, J. A., Scott, B. A., \& LePine, J. A. (2007). Trust, trustworthiness, and trust propensity: a meta-analytic test of their unique relationships with risk taking and job performance. Journal of Applied Psychology, 92, 909-927.

Cook, T. E., \& Gronke, P. (2005). The skeptical American: Revisiting the meanings of trust in government and confidence in institutions. The Journal of Politics, 67, 784-803.

Craig, S. C., Niemi, R. G., \& Silver, G. E. (1990). Political efficacy and trust: A report on the NES pilot study items. Political Behavior, 12(3), 289-314.

Cummings, L. L., \& Bromiley, P. (1996). The organizational trust inventory (OTI). In R. M. Kramer \& T. R. Tyler (Eds.), Trust in organizations: Frontiers of theory and research (pp. 261-287). Thousand Oaks, CA: Sage.

Currall, S. C., \& Judge, T. A. (1995). Measuring trust between organizational boundary role persons. Organizational Behavior and Human Decision Processes, 64(2), 151-170.

De Cremer, D., \& Alberts, H. J. (2004). When procedural fairness does not influence how positive I feel: The effects of voice and leader selection as a function of belongingness need. European Journal of Social Psychology, 34(3), 333-344.

De Cremer, D., \& Tyler, T. R. (2005). Managing group behavior: The interplay between procedural justice, sense of self, and cooperation. Advances in Experimental Social Psychology, 37, 151-218.

Dietz, G., \& Den Hartog, D. N. (2006). Measuring trust inside organisations. Personnel Review, $35(5), 557-588$.

Dimoka, A. (2010). What does the brain tell us about trust and distrust? Evidence from a functional neuroimaging study. MIS Quarterly, 34(2), 373-396.

Earle, T. C. (2010). Trust in risk management: A model-based review of empirical research. Risk Analysis, 30(4), 541-574.

Earle, T. C., \& Siegrist, M. (2006). Morality information, performance information, and the distinction between trust and confidence. Journal of Applied Social Psychology, 36(2), 383-416.

Easton, D. (1975). A re-assessment of the concept of political support. British Journal of Political Science, 5(4), 435-457.

Fiske, S. T. (1980). Attention and weight in person perception: The impact of negative and extreme behavior. Journal of Personality and Social Psychology, 38(6), 889-906.

Fiske, S. T., Cuddy, A. J., \& Glick, P. (2007). Universal dimensions of social cognition: Warmth and competence. Trends in cognitive sciences, 11(2), 77-83.

Fiske, S. T., Xu, J., Cuddy, A. C., \& Glick, P. (1999). (Dis) respecting versus (dis) liking: Status and interdependence predict ambivalent stereotypes of competence and warmth. Journal of Social Issues, 55(3), 473-489.

Frazier, M. L., Johnson, P. D., \& Fainshmidt, S. (2013). Development and validation of a propensity to trust scale. Journal of Trust Research, 3(2), 76-97. 
Frewer, L. J., Howard, C., Hedderley, D., \& Shepherd, R. (1996). What determines trust in information about food-related risks? Underlying psychological constructs. Risk Analysis, 16(4), 473-486.

Gau, J. M. (2012). Consent searches as a threat to procedural justice and police legitimacy: An analysis of consent requests during traffic stops. Criminal Justice Policy Review, 0887403412464547.

Gibson, J. L., Caldeira, G. A., \& Spence, L. K. (2003). Measuring attitudes toward the United States Supreme Court. American Journal of Polical Science, 47(2), 354-367.

Gibson, J. L., Caldeira, G. A., \& Spence, L. K. (2005). Why do people accept public policies they oppose? Testing legitimacy theory with a survey-based experiment. Political Research Quarterly, 58(2), 187-201.

Gillespie, N. A. (2003). Measuring trust in working relationships: The behavioral trust inventory. Paper presented at the Annual Meeting of the Academy of Management, Seattle, WA.

Gillespie, N. A., \& Mann, L. (2004). Transformational leadership and shared values: the building blocks of trust. Journal of Managerial Psychology, 19(6), 588-607. doi: doi:10.1108/02683940410551507

Grau, L., Chandler, B., Burton, B., \& Kolditz, D. (1991). Institutional loyalty and job satisfaction among nurse aides in nursing homes. Journal of Aging and Health, 3(1), 47-65.

Hamm, J. A. (2014). Understanding the role of trust in cooperation with a natural resources institution. Doctoral Dissertation. Department of Psychology. University of NebraskaLincoln. Lincoln, NE. Retrieved from http://digitalcommons.unl.edu/psychdiss/63/

Hamm, J. A., Hoffman, L., Bornstein, B. H., \& Tomkins, A. J. (in press). On the influence of trust in predicting rural land owner cooperation with natural resource management institutions. Journal of Trust Research.

Hamm, J. A., PytlikZillig, L. M., Herian, M. N., Bornstein, B. H., Tomkins, A. J., \& Hoffman, L. (2013). Deconstructing public confidence in state courts. Journal of Trust Research, 3, 11-31.

Hamm, J. A., PytlikZillig, L. M., Herian, M. N., Tomkins, A. J., Dietrich, H., \& Michaels, S. (2013). Trust and intention to comply with a water allocation decision: The moderating roles of knowledge and consistency. Ecology and Society, 18(4), 49.

Hamm, J. A., PytlikZillig, L. M., Tomkins, A. J., Herian, M. N., Bornstein, B. H., \& Neeley, E. (2011). Exploring separable components of institutional confidence. Behavioral Sciences and the Law, 29, 95-115.

Herian, M. N., Hamm, J. A., Tomkins, A. J., \& PytlikZillig, L. M. (2012). Public participation, procedural fairness, and evaluations of local governance: The moderating role of uncertainty. Journal of Public Administration Research and Theory, 22, 815-840.

Heyns, M., \& Rothmann, S. (2015). Dimensionality of trust: An analysis of the relations between propensity, trustworthiness and trust. SA Journal of Industrial Psychology, 41(1), 12 pages. doi: 10.4102/sajip.v41i1.1263

Hoy, W. K., \& Tschannen-Moran, M. (2003). The conceptualization and measurement of faculty trust in schools: The omnibus T-Scale. In W. K. Hoy \& C. Miskel (Eds.), Studies in leading and organizing schools (pp. 181-208). Greenwich, CT: Information Age Publishing.

Hu, L., \& Bentler, P. M. (1998). Fit indices in covariance structure modeling: Sensitivity to underparameterized model misspecification. Psychological Methods, 3(4), 424. 
Hu, L., \& Bentler, P. M. (1999). Cutoff criteria for fit indexes in covariance structure analysis: Conventional criteria versus new alternatives. Structural Equation Modeling, 6, 1-55.

Inoguchi, T., Mikami, S., \& Fujii, S. (2007). Social capital in East Asia: Comparative political culture in Confucian societies. Japanese Journal of Political Science, 8, 409-426.

Jackson, J., \& Gau, J. M. (2016). Carving up concepts? Differentiating between trust and legitimacy in public attitudes towards legal authority. In E. Shockley, T. M. S. Neal, L. M. PytlikZillig, \& B. H. Bornstein (Eds.), Interdisciplinary perspectives on trust: Towards theoretical and methodological integration (pp. 49-70). New York: Springer.

John, O. P., \& Benet-Martinez, V. (2000). Measurement: Reliability, construct validation, and scale construction. In H. T. Reis \& C. M. Judd (Eds.), Handbook of Research Methods in Social and Personality Psychology (pp. 339-369). New York: Cambridge University Press.

Jungermann, H., Pfister, H. R., \& Fischer, K. (1996). Credibility, information preferences, and information interests. Risk Analysis, 16(2), 251-261.

Kline, R. B. (2005). Principles and Practice of Structural Equation Modeling. 2005. New York, NY: Guilford.

Kohring, M., \& Matthes, J. (2007). Trust in news media development and validation of a multidimensional scale. Communication Research, 34(2), 231-252.

Kunda, Z. (1990). The case for motivated reasoning. Psychological Bulletin, 108(3), 480-498.

Levi, M. (1998). A state of trust. In M. Levi \& V. Braithwaite (Eds.), Trust and governance (pp. 77-101). New York: Russell Sage Foundation.

Lewicki, R. J., \& Bunker, B. B. (1995). Trust in relationships: A model of development and decline. In B. B. Bunker \& J. Z. Rubin (Eds.), Conflict, cooperation, and justice: Essays inspired by the work of Morton Deutsch (pp. 133-173). San Francisco, CA: Jossey-Bass.

Lewicki, R. J., McAllister, D. J., \& Bies, R. J. (1998). Trust and distrust: New relationships and realities. Academy of Management Review, 23, 438-458.

Li, P. P. (2008). Toward a geocentric framework of trust: An application to organizational trust. Management and Organization Review, 3, 413-439.

Lind, E. A., \& Tyler, T. R. (1988). The social psychology of procedural justice. New York: Plenum Press.

Lubell, M. (2007). Familiarity breeds trust: Collective action in a policy. The Journal of Politics, 69, 237-250.

Marsh, S., \& Dibben, M. R. (2005). Trust, untrust, distrust and mistrust-an exploration of the dark (er) side. In P. Herrmann, V. Issarny, \& S. Shiu (Eds.), Trust management: Third International Conference, iTrust Proceedings (pp. 17-33). New York: Springer.

Mason, W., \& Suri, S. (2012). Conducting behavioral research on Amazon's Mechanical Turk. Behavior Research Methods, 44(1), 1-23. doi: 10.3758/s13428-011-0124-6

May, P. J. (2004). Compliance motivations: Affirmative and negative bases. Law \& Society Review, 38(1), 41-68.

Mayer, R. C., \& Davis, J. H. (1999). The effect of the performance appraisal system on trust for management: A field quasi-experiment. Journal of Applied Psychology, 84(1), 123.

Mayer, R. C., Davis, J. H., \& Schoorman, F. D. (1995). An integrative model of organizational trust. Academy of Management Review, 20, 709-734.

McAllister, D. J. (1995). Affect-and cognition-based trust as foundations for interpersonal cooperation in organizations. Academy of Management Journal, 38(1), 24-59. 
McClendon, M. J. (1991). Acquiescence and recency response-order effects in interview surveys. Sociological Methods \& Research, 20(1), 60-103.

McEvily, B., \& Tortoriello, M. (2011). Measuring trust in organisational research: Review and recommendations. Journal of Trust Research, 1(1), 23-63.

McKnight, D. H., \& Chervany, N. L. (2001). Trust and distrust definitions: One bite at a time. Trust in Cyber-societies: Lecture Notes in Computer Science, 2246, $27-54$.

McKnight, D. H., \& Choudhury, V. (2006). Distrust and trust in B2C e-commerce: Do they differ? Paper presented at the Proceedings of the 8th international conference on Electronic commerce: The new e-commerce: innovations for conquering current barriers, obstacles and limitations to conducting successful business on the internet.

McKnight, D. H., Choudhury, V., \& Kacmar, C. (2002). Developing and validating trust measures for e-commerce: an integrative typology. Information Systems Research, 13, 334-359.

McKnight, D. H., Cummings, L. L., \& Chervany, N. L. (1998). Initial trust formation in new organizational relationships. Academy of Management Review, 23, 473-490.

Mentovich, A., Rhee, E., \& Tyler, T. R. (2014). My life for a voice: The influence of voice on health-care decisions. Social Justice Research, 27(1), 99-117.

Metlay, D. (1999). Institutional trust and confidence: A journey into a conceptual quagmire. In G. T. Cvetkovich \& R. Lofstedt (Eds.), Social trust and the management of risk (pp. 100116). London: Earthscan.

Möllering, G. (2006). Trust: Reason, routine, reflexivity. Oxford: Elsevier.

Muthén, L. K., \& Muthén, B. O. (2013). Mplus statistical software version 7.11. Los Angeles, CA: Muthén \& Muthén.

Nannestad, P. (2008). What have we learned about generalized trust, if anything? Annual Review of Political Science, 11, 413-436.

National Center for State Courts. (2000). National conference on public trust and confidence in the judicial system: National action plan: A guide for state and national organizations. Retrieved 15 May, 2015, from http://cdm16501.contentdm.oclc.org/cdm/ref/collection/ctcomm/id/20

Newton, K. (2001). Trust, social capital, civil society, and democracy. International Political Science Review, 22(2), 201-214.

Obama, B. (2009, January 21). Open government initiative: Transparency, participation, collaboration. Retrieved 15 May, 2015, from http://www.whitehouse.gov/open

Ostrom, E. (1998). A behavioral approach to the rational choice theory of collective action: Presidential address, American Political Science Association, 1997. American Political Science Review, 92(01), 1-22.

Peng, L. (2014). A comparative analysis of political confidence in the BRICS countries. Japanese Journal of Political Science, 15, 417-441.

Pennington, R., Wilcox, H. D., \& Grover, V. (2003). The role of system trust in business-toconsumer transactions. Journal of Management Information Systems, 20(3), 197-226.

Pirson, M., \& Malhotra, D. (2007). What matters to whom? Managing trust across multiple stakeholder groups. Working Paper No. 39, Cambridge, MA: Harvard University, Hauser Center for Nonprofit Organizations.

Pirson, M., \& Malhotra, D. (2011). Foundations of organizational trust: What matters to different stakeholders? Organization Science, 22, 1087-1104. 
Poortinga, W., \& Pidgeon, N. F. (2003). Exploring the dimensionality of trust in risk regulation. Risk Analysis, 23(5), 961-972.

Poortinga, W., \& Pidgeon, N. F. (2006). Prior attitudes, salient value similarity, and dimensionality: Toward an integrative model of trust in risk regulation. Journal of Applied Social Psychology, 36(7), 1674-1700.

Putnam, R. D. (2000). Bowling alone: The collapse and revival of American community. New York: Simon \& Schuster.

PytlikZillig, L. M., Abdel-Monem, T., Herian, M. N., Williams, D., \& Tomkins, A. J. (2011). Taking Charge 2011 Final Report. University of Nebraska Public Policy Center, Lincoln, NE.

PytlikZillig, L. M., \& Kimbrough, C. D. (2016). Consensus on conceptualizations and definitions of trust: Are we there yet? In E. Shockley, T. M. S. Neal, L. M. PytlikZillig, \& B. H. Bornstein (Eds.), Interdisciplinary perspectives on trust: Towards theoretical and methodological integration (pp. 17-47). New York: Springer.

PytlikZillig, L. M., Tomkins, A. J., Herian, M. N., Hamm, J. A., \& Abdel-Monem, T. (2012). Public input methods and confidence in government. Transforming Government: People, Process and Policy, 6, 92-111.

PytlikZillig, L. M., Tomkins, A. J., Muhlberger, P., Pardy, R. L., Morris, J. T., Dzenis, Y. A., .. . Collins, T. P. (2011). Using public engagements to provide input and insights into policy, legal, ethical, and other impacts of science. The International Journal of Science in Society, 2, 273-290.

Rosenberg, S., Nelson, C., \& Vivekananthan, P. (1968). A multidimensional approach to the structure of personality impressions. Journal of Personality and Social Psychology, 9(4), 283.

Rotter, J. B. (1980). Interpersonal trust, trustworthiness, and gullibility. American Psychologist, 35(1), 1-7.

Rousseau, D. M., Sitkin, S. B., Burt, R. S., \& Camerer, C. (1998). Not so different after all: a cross-discipline view of trust. Academy of Management Review, 23, 393-404.

Saxe, R., \& Weitz, B. A. (1982). The SOCO scale: A measure of the customer orientation of salespeople. Journal of Marketing Research, 19, 343-351.

Schoorman, F. D., Mayer, R. C., \& Davis, J. H. (2007). An integrative model of organizational trust: Past, present, and future. Academy of Management Review, 32(2), 344-354.

Schumacker, R. E., \& Lomax, R. (2010). Structural equation modeling: New York: Routledge, Taylor \& Francis Group.

Schwarz, G. (1978). Estimating the dimension of a model. The annals of statistics, 6(2), 461464.

Sharp, E. A., Thwaites, R., Curtis, A., \& Millar, J. (2013). Trust and trustworthiness: conceptual distinctions and their implications for natural resources management. Journal of Environmental Planning and Management, 56(8), 1246-1265.

Shepherd, S., \& Kay, A. C. (2012). On the perpetuation of ignorance: system dependence, system justification, and the motivated avoidance of sociopolitical information. Journal of Personality and Social Psychology, 102(2), 264-280.

Sheppard, B. H., \& Sherman, D. M. (1998). The grammars of trust: A model and general implications. Academy of Management Review, 23(3), 422-437. 
Shockley, E., Neal, T. M. S., PytlikZillig, L. M., \& Bornstein, B. H. (2016). Interdisciplinary perspectives on trust: Towards theoretical and methodological integration. New York: Springer.

Smith, J. W., Leahy, J. E., Anderson, D. H., \& Davenport, M. A. (2013). Community/agency trust: A measurement instrument. Society \& Natural Resources, 26(4), 472-477.

Tan, S. J. \& Tambyah, S. K. (2011). Generalized trust and trust in institutions in Confucian Asia. Social Indicators Research, 103, 357-377.

Tyler, T. R. (2006). Why people obey the law: Procedural justice, legitimacy, and compliance. Princeton, NJ. (Reissue; originally published in 1990): Princeton University Press.

Tyler, T. R. (2007-2008). Procedural justice and the courts. Court Review, 44, 26-31.

Tyler, T. R., \& Fagan, J. (2008). Legitimacy and cooperation: Why do people help the police fight crime in their communities? Ohio State Journal of Criminal Law, 6, 231-275.

Tyler, T. R., \& Huo, Y. J. (2002). Trust in the law: Encouraging public cooperation with the police and courts. New York: Russell-Sage Foundation.

Tyler, T. R., \& Lind, E. A. (1992). A relational model of authority in groups. In M. P. Zanna (Ed.), Advances in Experimental Social Psychology (Vol. 25, pp. 115-199). SanDiego, CA: Academic Press.

Uslaner, E. M. (2002). The moral foundations of trust. New York: Cambridge University Press.

Van De Walle, S., \& Six, F. (2013). Trust and distrust as distinct concepts: Why studying distrust in institutions is important. Journal of Comparative Policy Analysis: Research and Practice, 1-17. doi: 10.1080/13876988.2013.785146

Vigoda-Gadot, E., \& Mizrahi, S. (2014). Managing democracies in turbulent times: Trust, performance, and governance in modern states. New York: Springer.

Warren, M. E. (1999). Democracy and trust. New York: Cambridge University Press.

Watson, D. (1992). Correcting for Acquiescent Response Bias in the Absence of a Balanced Scale An Application to Class Consciousness. Sociological Methods \& Research, 21(1), $52-88$.

Wojciszke, B., \& Abele, A. E. (2008). The primacy of communion over agency and its reversals in evaluations. European Journal of Social Psychology, 38(7), 1139-1147.

Wren, T. (2014). Philosophical moorings. In L. Nucci, D. Narvaez, \& T. Krettanauer (Eds.), Handbook of moral and character education (2nd ed., pp. 11-29). New York: Routledge.

Wu, X. N., \& Wang, E. P. (2013). Outcome favorability as a boundary condition to voice effect on people's reactions to public policymaking. Journal of Applied Social Psychology, 43(2), 329-337.

Zmerli, S., \& Newton, K. (2008). Social trust and attitudes toward democracy. Public Opinion Quarterly, 72(4), 706-724. 
Table 1

Conceptual measurement models of trust-relevant constructs examined in the current studies

\begin{tabular}{|c|c|c|c|c|c|c|}
\hline $\begin{array}{l}\text { MF: Many-Factor } \\
\text { Constructs* }\end{array}$ & $\begin{array}{l}\text { 6F: Six- } \\
\text { Factor }\end{array}$ & $\begin{array}{l}\text { 5F: Five- } \\
\text { Factor }\end{array}$ & $\begin{array}{l}\text { 4Fa: Four- } \\
\text { Factor, } \\
\text { Ability/ } \\
\text { Warmth }\end{array}$ & $\begin{array}{l}\text { 4Fb: Four- } \\
\text { Factor, } \\
\text { Positive/ } \\
\text { Negative }\end{array}$ & $\begin{array}{l}\text { 3F: Three- } \\
\text { Factor }\end{array}$ & $\begin{array}{l}\text { 2F: Two- } \\
\text { Factor }\end{array}$ \\
\hline $\begin{array}{l}\text { Dispositional } \\
\text { Trust }^{1,2,3}\end{array}$ & $\begin{array}{c}\text { Disposition. } \\
\text { Trust }\end{array}$ & $\begin{array}{l}\text { Disposition. } \\
\text { Trust }\end{array}$ & $\begin{array}{c}\text { Disposition. } \\
\text { Trust }\end{array}$ & $\begin{array}{c}\text { Disposition. } \\
\text { Trust }\end{array}$ & $\begin{array}{c}\text { Disposition. } \\
\text { Trust }\end{array}$ & $\begin{array}{c}\text { Disposition. } \\
\text { Trust }\end{array}$ \\
\hline $\begin{array}{l}\text { Direct/Unspecified } \\
\text { Trust }^{1,2,3} \\
\text { Loyal Trust }^{1,2}\end{array}$ & Trust & Trust & Trust & Trust & Trust & \multirow{10}{*}{$\begin{array}{c}\text { Institutional } \\
\text { Trust }\end{array}$} \\
\hline $\begin{array}{l}\text { Perceived } \\
\text { Competence } \\
\end{array}$ & \multirow{2}{*}{$\begin{array}{l}\text { Perceived } \\
\text { Ability }\end{array}$} & \multirow{2}{*}{$\begin{array}{l}\text { Perceived } \\
\text { Ability }\end{array}$} & \multirow{2}{*}{$\begin{array}{l}\text { Perceived } \\
\text { Ability }\end{array}$} & \multirow{7}{*}{$\begin{array}{l}\text { Positive } \\
\text { Attitudes }\end{array}$} & \multirow{9}{*}{$\begin{array}{l}\text { Perceived } \\
\text { Trustworth. }\end{array}$} & \\
\hline $\begin{array}{l}\text { Perceived } \\
\text { Legitimacy }\end{array}$ & & & & & & \\
\hline Perceived Care ${ }^{1,2,3,4}$ & Perceived & Perceived & \multirow{7}{*}{$\begin{array}{l}\text { Perceived } \\
\text { Warmth }\end{array}$} & & & \\
\hline Perceived Voice ${ }^{1,2,3,4}$ & Benevolence & Benevolence & & & & \\
\hline $\begin{array}{l}\text { Perceived } \\
\text { Honesty }\end{array}$ & \multirow{2}{*}{$\begin{array}{l}\text { Perceived } \\
\text { Integrity }\end{array}$} & \multirow{5}{*}{$\begin{array}{l}\text { Perceived } \\
\text { Integrity }\end{array}$} & & & & \\
\hline $\begin{array}{l}\text { Perceived } \\
\text { Fairness }\end{array}$ & & & & & & \\
\hline $\begin{array}{l}\text { Perceived Shared } \\
\text { Values }{ }^{1,2,3,4}\end{array}$ & \multirow{2}{*}{$\begin{array}{l}\text { Values/ } \\
\text { Identificat. }\end{array}$} & & & & & \\
\hline Cynical Beliefs ${ }^{1,2,3,4}$ & & & & & & \\
\hline Perceived Bias ${ }^{1,3,4}$ & $\begin{array}{l}\text { Integrity } \\
\text { (Cont.) }\end{array}$ & & & $\begin{array}{l}\text { Negative } \\
\text { Attitudes }\end{array}$ & & \\
\hline
\end{tabular}

*Many-Factor (MF) Model treats each construct as a factor not combined with any other constructs. Other models combine indicated factors separated in the MF model. Superscripts indicate constructs ${ }^{1}$ included in Study 1 ,

${ }^{2}$ included in Study 2, ${ }^{3}$ included in Study 3, and ${ }^{4}$ included in Study 4. Abbreviations: Identificat. = Identification, Trustworth. $=$ Trustworthiness, Disposition. $=$ Dispositional. 
Table 2

Construct Measures and Sources

\begin{tabular}{ll}
\hline \multicolumn{1}{c}{ Construct } & \multicolumn{1}{c}{ Primary Sources and Inspiration for Items } \\
\hline Bias & (Lind \& Tyler, 1988) \\
Care & (Mayer \& Davis, 1999) \\
Competence & (Mayer \& Davis, 1999) \\
Cynical Beliefs & (Tyler \& Huo, 2002) \\
Dispositional Trust & General Social Survey (GSS), International Personality Item Pool (IPIP) \\
Fairness & (Lind \& Tyler, 1988) \\
Honesty & (Mayer \& Davis, 1999; Tyler \& Huo, 2002) \\
Legitimacy & (Tyler, 2006) \\
Loyal Trust & (Gibson, Caldeira, \& Spence, 2003; Grau, Chandler, Burton, \& Kolditz, \\
& 1991) \\
Shared Values & (Earle \& Siegrist, 2006; Poortinga \& Pidgeon, 2006) \\
Unspecified Trust & American National Election Studies (ANES) \\
Voice & (Tyler, 2006) \\
\hline
\end{tabular}

Note. Items used in our studies were adapted from or inspired by the listed sources, not used verbatim. Many of the items were also used in prior studies (Hamm, PytlikZillig, Herian, Bornstein, et al., 2013; Hamm, PytlikZillig, Herian, Tomkins, et al., 2013; Hamm et al., 2011). 
Table 3

Results from Study 1 (Police Context) Confirmatory Factor Analyses

\begin{tabular}{|c|c|c|c|c|c|c|c|c|c|}
\hline Model & $\begin{array}{c}\text { Rescaled } \\
\Delta-2 \mathrm{LL} \\
\text { from MF } \\
(\Delta d f)\end{array}$ & $X^{2}$ & $D f$ & CFI & TLI & $\begin{array}{l}\text { RMSEA } \\
(95 \% \text { CI })\end{array}$ & SRMR & AIC & $\mathrm{BIC}$ \\
\hline \multicolumn{10}{|l|}{ Phase 1: a priori Models } \\
\hline 1F: Compact model & $\begin{array}{c}3888.8^{*} \\
(46)\end{array}$ & 2751.368 & 594 & .832 & .822 & $\begin{array}{c}.073 * \\
(.070-.076)\end{array}$ & .083 & 63741.5 & 64229.8 \\
\hline 2F: Dispositional trust \& institutional trust & $\begin{array}{c}3577.9^{*} \\
(45)\end{array}$ & 2307.251 & 593 & .867 & .859 & $\begin{array}{c}.065^{*} \\
(.062-.068)\end{array}$ & $.076^{*}$ & 63105.9 & 63598.7 \\
\hline $\begin{array}{l}\text { 3F: Dispositional trust \& institutional trust } \\
\text { \& institutional trustworthiness }\end{array}$ & $\begin{array}{c}3551.9^{*} \\
(43)\end{array}$ & 2298.867 & 591 & .867 & .859 & $\begin{array}{c}.065^{*} \\
(.062-.068)\end{array}$ & $.075^{*}$ & 63098.2 & 68600.0 \\
\hline $\begin{array}{l}\text { 4Fa: Dispositional trust } \& \text { institutional trust } \\
\text { \& ability/warmth trustworthiness }\end{array}$ & $\begin{array}{l}3612.8^{*} \\
(40)\end{array}$ & 2287.803 & 588 & .868 & .859 & $\begin{array}{c}.065^{*} \\
(.062-.068)\end{array}$ & $.075^{*}$ & 63081.5 & 63596.8 \\
\hline $\begin{array}{l}\text { 4Fb: Dispositional trust \& institutional trust } \\
\& \text { positive/negative trustworthiness }\end{array}$ & $\begin{array}{l}2921.1^{*} \\
(40)\end{array}$ & 1637.005 & 588 & $.919 *$ & $.913^{*}$ & $\begin{array}{c}.051 * * \\
(.048-.054)\end{array}$ & $.067 *$ & 62168.1 & 62683.5 \\
\hline $\begin{array}{l}\text { 5F: Dispositional trust \& institutional trust } \\
\& \text { ability/benevolence/integrity (ABI) }\end{array}$ & $\begin{array}{c}3675.9^{*} \\
(36)\end{array}$ & 2283.379 & 584 & .868 & .858 & $\begin{array}{c}.065^{*} \\
(.063-.068)\end{array}$ & $.075^{*}$ & 63076.9 & 63610.3 \\
\hline $\begin{array}{l}\text { \#6F: Dispositional trust \& institutional } \\
\text { trust \& ability/ benevolence/ integrity/ } \\
\text { values (ABIV) }\end{array}$ & $\begin{array}{c}3684.3^{*} \\
(31)\end{array}$ & 2198.225 & 579 & .874 & .863 & $\begin{array}{c}.064^{*} \\
(.061-.067)\end{array}$ & $.075^{*}$ & 62960.3 & 63516.3 \\
\hline \#MF: Many-factor model & N/A & 1050.719 & 440 & $.944^{*}$ & $.933^{*}$ & $\begin{array}{c}.045^{* *} \\
(.042-.049)\end{array}$ & $.060 *$ & $57564.6^{* *}$ & $58260.8 * *$ \\
\hline \multicolumn{10}{|l|}{ Phase 2: Post hoc (data driven) models } \\
\hline $\begin{array}{l}\text { PH-3F: Dispositional trust \& negative and } \\
\text { positive trust/trustworthiness }\end{array}$ & $\begin{array}{l}2980.4^{*} \\
(43)\end{array}$ & 1646.667 & 591 & $.918^{*}$ & $.913^{*}$ & $\begin{array}{c}.051^{*} \\
(.048-.054)\end{array}$ & $.067 *$ & 62174.0 & 62675.8 \\
\hline $\begin{array}{l}\text { PH-1HO: Positive trust and trustworthiness } \\
\text { on higher-order factor }\end{array}$ & \multicolumn{9}{|c|}{ (Model would not converge) } \\
\hline
\end{tabular}

Note. \#Models resulted in a non-positive definite PSI matrix. *Meets liberal criteria for goodness of fit, or $p<.05$ for rescaled -2 $\Delta$ LL test; **Meets conservative criteria for goodness of fit listed in text, or obtained best AIC/BIC of all tested models. 
Table 4

Study 1 (Police Context) Item Standardized Loadings from Best-Fitting (4Fb) Model without Errors

\begin{tabular}{|c|c|c|c|c|}
\hline Dimension & Item Wording & $\begin{array}{l}\text { Stand. } \\
\text { Loading }\end{array}$ & S.E. & $\operatorname{var}_{\mathrm{e}}$ \\
\hline \multirow{3}{*}{$\begin{array}{l}\text { Dispositional } \\
\text { Trust }\end{array}$} & 1. I trust what most people say. & .588 & .037 & .655 \\
\hline & 2. Most people try to be fair. & .875 & .027 & .235 \\
\hline & 3. Most people try to be helpful. & .806 & .032 & .351 \\
\hline \multirow{6}{*}{ Trust } & $\begin{array}{l}\text { Direct/Unspecified Trust } \\
\text { 4. My confidence in the Lincoln Police Department is high. }\end{array}$ & .864 & .015 & .254 \\
\hline & $\begin{array}{l}\text { 5. The Lincoln Police Department performs its functions as it } \\
\text { should. }\end{array}$ & .886 & .014 & .216 \\
\hline & 6. I trust the Lincoln Police Department. & .832 & .016 & .308 \\
\hline & $\begin{array}{l}\text { Loyal Trust } \\
\text { 7. I have respect for the Lincoln Police Department, even when I } \\
\text { disagree with its actions. }\end{array}$ & .747 & .028 & .442 \\
\hline & 8. I feel a sense of loyalty to the Lincoln Police Department. & .736 & .026 & .459 \\
\hline & $\begin{array}{l}\text { 9. I generally support the Lincoln Police Department, even when I } \\
\text { disagree with some of its actions. }\end{array}$ & .777 & .026 & .397 \\
\hline \multirow{18}{*}{$\begin{array}{c}\text { Positive } \\
\text { Trustworthiness }\end{array}$} & $\begin{array}{l}\text { Competence } \\
\text { 10. The Lincoln Police Department is competent to do its job. }\end{array}$ & .836 & .021 & .301 \\
\hline & $\begin{array}{l}\text { 11. The Lincoln Police Department is made up of highly qualified } \\
\text { individuals. }\end{array}$ & .874 & .013 & .236 \\
\hline & $\begin{array}{l}\text { 12. The Lincoln Police Department has the skills necessary to do its } \\
\text { job. }\end{array}$ & .864 & .017 & .254 \\
\hline & $\begin{array}{l}\text { Legitimacy } \\
\text { 13. Fair procedures are used to select individuals in the Lincoln } \\
\text { Police Department. }\end{array}$ & .779 & .031 & .393 \\
\hline & 14. The Lincoln Police Department uses its power appropriately. & .853 & .016 & .273 \\
\hline & 15. The Lincoln Police Department is a legitimate authority. & .771 & .022 & .405 \\
\hline & $\begin{array}{l}\text { Shared Values } \\
\text { 16. The Lincoln Police Department shares my values. }\end{array}$ & .805 & .020 & .352 \\
\hline & $\begin{array}{l}\text { 17.I share the Lincoln Police Department's values about how the } \\
\text { Lincoln Police Department should do its job. }\end{array}$ & .799 & .028 & .362 \\
\hline & 18. The Lincoln Police Department supports my values. & .833 & .017 & .306 \\
\hline & $\begin{array}{l}\text { Care } \\
\text { 19. The Lincoln Police Department has the community's best } \\
\text { interests in mind when it acts. }\end{array}$ & .858 & .014 & .264 \\
\hline & $\begin{array}{l}\text { 20. For the most part, the Lincoln Police Department acts out of } \\
\text { concern for Lincoln residents. }\end{array}$ & .775 & .031 & .399 \\
\hline & $\begin{array}{l}\text { 21. The Lincoln Police Department puts aside personal interests in } \\
\text { order to make decisions that are right for the community. }\end{array}$ & .814 & 0.021 & .338 \\
\hline & $\begin{array}{l}\text { Voice } \\
\text { 22. The Lincoln Police Department listens to my opinions. }\end{array}$ & .705 & .024 & .503 \\
\hline & $\begin{array}{l}\text { 23. People have great say in important Lincoln Police Department } \\
\text { decisions. }\end{array}$ & .594 & .037 & .647 \\
\hline & $\begin{array}{l}\text { 24. Residents can influence the Lincoln Police Department } \\
\text { decisions. }\end{array}$ & .272 & .052 & .926 \\
\hline & $\begin{array}{l}\text { Honesty } \\
\text { 25. Mostly, the Lincoln Police Department lacks integrity. }\end{array}$ & .461 & .058 & .787 \\
\hline & $\begin{array}{l}\text { 26. The Lincoln Police Department is mostly made up of honest } \\
\text { individuals. }\end{array}$ & .883 & .012 & .220 \\
\hline & $\begin{array}{l}\text { 27. Even when it is difficult, the Lincoln Police Department still } \\
\text { maintains its values. }\end{array}$ & .869 & .016 & .245 \\
\hline
\end{tabular}




\section{Fairness}

$\begin{array}{llll}\text { 28. The Lincoln Police Department uses fair procedures to make its } & .883 & .013 & .220\end{array}$ decisions.

29. The Lincoln Police Department generally has been fair in its dealings with the community.

$.828 \quad .020 \quad .314$

30. In general, I have been treated fairly by the Lincoln Police Department.

$\begin{array}{lll}.739 & .029 \quad .454\end{array}$ Cynical Beliefs (-)

31. The Lincoln Police Department does not protect my interests. $\quad \begin{array}{llll}712 & .040 & .493\end{array}$

32. The Lincoln Police Department is not representative of the community.

$.675 \quad .039 \quad .544$

33. The Lincoln Police Department is out of touch with what's going

Negative Trustworthiness

$(-)$ on in the community.

$.660 \quad .041 \quad .565$ Bias (-)

34. The Lincoln Police Department acts in the interests of some groups over others.

35. The actions of the Lincoln Police Department are biased. $\quad \begin{array}{llll}.707 & .036 & .501\end{array}$

36. The Lincoln Police Department is overly influenced by special interest groups. $\begin{array}{lll}.681 \quad .045 & .537\end{array}$

Note. Stand. Loading = standardized factor loading, S.E. = standard error, var $_{\mathrm{e}}=$ residual (error) variance. $(-)$ Negative construct. 
Table 5

Study 1 (Police Context) Latent Construct Correlations (Reliability [W] on the Diagonal)

\begin{tabular}{lcccc}
\hline & 1 & 2 & 3 & 4 \\
\hline $1-$ Dispostional Trust & $\mathbf{( . 8 0 )}$ & & & \\
$2-$ Trust & .247 & $(.92)$ & & \\
3 - Positive Trustworthiness & .270 & .990 & $(.97)$ & $(.83)$ \\
$4-$ Negative trustworthiness (-) & $-.075^{\text {ns }}$ & -.392 & -.405 & \multicolumn{4}{l}{ (evel. (-) Negatively valenced } \\
Note. ${ }^{\text {ns }}$ Non-significant correlation. All other correlations are significant at the $p<.05$ level \\
construct.
\end{tabular}


Table 6

Results from Study 2 (Local Governance Context) Confirmatory Factor Analyses

\begin{tabular}{|c|c|c|c|c|c|c|c|c|c|}
\hline Model & $\begin{array}{l}\text { Rescaled } \\
\Delta-2 \mathrm{LL} \\
\text { from MF } \\
(\Delta d f)\end{array}$ & $X^{2}$ & $d f$ & CFI & TLI & $\begin{array}{l}\text { RMSEA } \\
(95 \% \mathrm{CI})\end{array}$ & SRMR & AIC & $\mathrm{BIC}$ \\
\hline \multicolumn{10}{|l|}{ Phase 1: A priori models } \\
\hline 1F: Compact model & $\begin{array}{l}1570.0^{*} \\
(55)\end{array}$ & 3010.152 & 560 & .865 & .857 & $\begin{array}{c}.070^{*} \\
(.068-.073)\end{array}$ & $.062 *$ & 74271.8 & 74774.9 \\
\hline 2F: Dispositional trust \& institutional trust & $\begin{array}{c}984.8^{*} \\
(54)\end{array}$ & 2268.066 & 559 & $.906^{*}$ & $.900 *$ & $\begin{array}{c}.059 * * \\
(.056-.061)\end{array}$ & $.043 * *$ & 73240.6 & 73748.4 \\
\hline $\begin{array}{l}\text { 3F: Dispositional trust \& institutional trust } \\
\text { \& institutional trustworthiness }\end{array}$ & $\begin{array}{l}929.1 * \\
(52)\end{array}$ & 2210.809 & 557 & $.909 *$ & $.903 *$ & $\begin{array}{c}.058 * * \\
(.055-.060)\end{array}$ & $.043 * *$ & 73167.2 & 73684.7 \\
\hline $\begin{array}{l}\text { 4Fa: Dispositional trust \& institutional trust } \\
\text { \& ability/warmth trustworthiness }\end{array}$ & $\begin{array}{c}799.5^{*} \\
(49)\end{array}$ & 2047.334 & 554 & $.918^{*}$ & $.912 *$ & $\begin{array}{c}.055^{* *} \\
(.052-.058)\end{array}$ & $.041 * *$ & 72942.2 & 73474.1 \\
\hline $\begin{array}{l}\text { 4Fb: Dispositional trust } \& \text { institutional trust } \\
\quad \& \text { positive/negative trustworthiness }\end{array}$ & $\begin{array}{c}837.9 * \\
(49)\end{array}$ & 2104.012 & 554 & $.915^{*}$ & $.908 *$ & $\begin{array}{c}.056 * * \\
(.054-.059)\end{array}$ & $.042 * *$ & 73024.3 & 73556.1 \\
\hline $\begin{array}{l}\text { 5F: Dispositional trust \& institutional trust \& } \\
\text { ability/benevolence/integrity (ABI) }\end{array}$ & $\begin{array}{c}757.9^{*} \\
(45)\end{array}$ & 2000.513 & 550 & $.920^{*}$ & $.914^{*}$ & $\begin{array}{c}.054 * * \\
(.052-.057)\end{array}$ & $.041 * *$ & 72883.6 & 73434.6 \\
\hline $\begin{array}{l}\text { 6F: Dispositional trust \& institutional trust } \\
\text { \& ability/benevolence/integrity/values } \\
\text { (ABIV) }\end{array}$ & $\begin{array}{c}624.1^{*} \\
(40)\end{array}$ & 1856.578 & 545 & $.928^{*}$ & $.921 *$ & $\begin{array}{c}.052 * * \\
(.049-.055)\end{array}$ & $.040 * *$ & 72697.6 & 73272.5 \\
\hline MF: Many-factor model & N/A & 1159.568 & 505 & $.964 * *$ & $.958 * *$ & $\begin{array}{c}.038 * * \\
(.035-.041)\end{array}$ & $.037 * *$ & $71817.1 * *$ & $72583.7 * *$ \\
\hline \multicolumn{10}{|l|}{ Phase 2: Post hoc (data driven) models } \\
\hline $\begin{array}{l}\text { PH-HO1: Higher-order factor for all } \\
\text { institutional trust/trustworthiness } \\
\text { variables }\end{array}$ & $\begin{array}{c}256.9^{*} \\
(44)\end{array}$ & 1422.106 & 549 & $.952 * *$ & $.948^{*}$ & $\begin{array}{c}.042 * * \\
(.040-.045)\end{array}$ & $.041 * *$ & 72086.7 & 72642.4 \\
\hline
\end{tabular}

Note. $*$ Meets liberal criteria for goodness of fit, or $p<.05$ for rescaled $-2 \Delta \mathrm{LL}$ test; $* *$ Meets conservative criteria for goodness of fit listed in text, or obtained best AIC/BIC of all tested models. 
Table 7

Study 2 (Local Governance Context) Item Standardized Loadings from Best-Fitting (MF) Model

\begin{tabular}{|c|c|c|c|c|}
\hline Dimension & Item Wording & $\begin{array}{l}\text { Stand. } \\
\text { Loading }\end{array}$ & S.E. & $\operatorname{var}_{\mathrm{e}}$ \\
\hline \multirow{5}{*}{$\begin{array}{l}\text { Dispositional } \\
\text { Trust }\end{array}$} & 1. I trust what people say. & .674 & .027 & .545 \\
\hline & 2. I believe that others have good intentions. & .780 & .032 & .391 \\
\hline & 3. I believe most people try to be fair. & .816 & .025 & .335 \\
\hline & 4. I distrust people. $(r)$ & 699 & .038 & .511 \\
\hline & 5. I suspect hidden motives in others. $(r)$ & 699 & .038 & .688 \\
\hline \multirow{3}{*}{$\begin{array}{c}\text { Direct/ } \\
\text { Unspecified } \\
\text { Trust }\end{array}$} & 6. My confidence in Lincoln city government is high. & .910 & .010 & .172 \\
\hline & 7. I have confidence in Lincoln city government to do its job. & .919 & .008 & .156 \\
\hline & $\begin{array}{l}\text { 8. I trust the Lincoln City government to perform its functions as it } \\
\text { should. }\end{array}$ & 919 & .008 & .226 \\
\hline \multirow{3}{*}{ Loyal Trust } & $\begin{array}{l}\text { 9. I have respect for Lincoln city government officials, even when I } \\
\text { disagree with a decision they make. }\end{array}$ & 762 & .024 & .420 \\
\hline & 10.I feel a sense of loyalty to the Lincoln city government. & .807 & .016 & .349 \\
\hline & $\begin{array}{l}\text { 11.I generally support the Lincoln city government even when I } \\
\text { disagree with some of its decisions. }\end{array}$ & .823 & .018 & .323 \\
\hline \multirow{2}{*}{ Competence } & $\begin{array}{l}\text { 12. Most decision makers of Lincoln city government are competent to } \\
\text { meet their responsibilities. }\end{array}$ & .863 & .013 & .255 \\
\hline & $\begin{array}{l}\text { 13. Lincoln city government is made up of highly qualified } \\
\text { individuals. }\end{array}$ & .893 & .012 & .202 \\
\hline \multirow{5}{*}{ Legitimacy } & 14. The Lincoln City government is a legitimate governing body. & .774 & .024 & .401 \\
\hline & 15. The Lincoln City government is a valid source of authority. & .824 & .022 & .321 \\
\hline & $\begin{array}{l}\text { 16. The members of the Lincoln City government are chosen through } \\
\text { fair elections. }\end{array}$ & .670 & .027 & .552 \\
\hline & 17. The procedures followed by Lincoln city government are lawful. & .730 & .031 & .467 \\
\hline & 18. The Lincoln City government uses its power appropriately & .800 & .029 & .360 \\
\hline \multirow{3}{*}{$\begin{array}{l}\text { Shared } \\
\text { Values }\end{array}$} & 19.I believe Lincoln city government shares my values. & .893 & .011 & .203 \\
\hline & $\begin{array}{l}\text { 20. To the extent that I understand them, I share Lincoln city } \\
\text { government's values regarding Lincoln's future. }\end{array}$ & .824 & .016 & .321 \\
\hline & $\begin{array}{l}\text { 21. I believe that Lincoln city government supports my values when it } \\
\text { makes decisions. }\end{array}$ & 899 & .011 & .192 \\
\hline \multirow{3}{*}{$\begin{array}{l}\text { Cynical } \\
\text { Beliefs (-) }\end{array}$} & $\begin{array}{l}\text { 22. The opinions of the Lincoln City Government represent the values } \\
\text { of people in power rather than the values of people like me. }\end{array}$ & 742 & .026 & .449 \\
\hline & 23. The Lincoln City government does not protect my interests. & .823 & .025 & .323 \\
\hline & $\begin{array}{l}\text { 24. The Lincoln City government uses its power to try to control } \\
\text { people like me. }\end{array}$ & .733 & .025 & .463 \\
\hline \multirow{3}{*}{ Care } & $\begin{array}{l}\text { 25. Lincoln city government has residents' best interests in mind when } \\
\text { it makes decisions. }\end{array}$ & .880 & .010 & .226 \\
\hline & $\begin{array}{l}\text { 26. Most members of the Lincoln city government care about residents } \\
\text { in the area that they regulate. }\end{array}$ & .814 & .016 & .337 \\
\hline & $\begin{array}{l}\text { 27. Lincoln city government officials care about how the policies they } \\
\text { make will affect Lincoln residents. }\end{array}$ & .860 & .013 & .260 \\
\hline \multirow{4}{*}{ Voice } & 28. I feel like Lincoln city government listens to my opinions. & .896 & .010 & .197 \\
\hline & $\begin{array}{l}\text { 29. Residents have great say in important Lincoln city government } \\
\text { decisions. }\end{array}$ & .827 & .019 & .315 \\
\hline & 30. Residents can influence Lincoln city government decisions. & .752 & .022 & .434 \\
\hline & $\begin{array}{l}\text { 31. I can freely express my points of view to the Lincoln City } \\
\text { government. }\end{array}$ & 651 & .025 & .576 \\
\hline \multirow{2}{*}{ Honesty } & 32. Most officials in the Lincoln city government lack integrity. & .815 & .020 & .335 \\
\hline & 33. Lincoln city government is made up of mostly honest individuals. & .863 & .018 & .255 \\
\hline
\end{tabular}




\begin{tabular}{ccccc}
\hline Dimension & \multicolumn{1}{c}{ Item Wording } & $\begin{array}{c}\text { Stand. } \\
\text { Loading }\end{array}$ & S.E. & var $_{\mathrm{e}}$ \\
\hline \multirow{2}{*}{ Fairness } & $\begin{array}{l}\text { 34.I think that the Lincoln city government uses fair procedures to } \\
\text { make its decisions. }\end{array}$ & .886 & .012 & .215 \\
& $\begin{array}{l}\text { 35.The procedures used by the Lincoln city government to make its } \\
\text { budgetary decisions are fair. }\end{array}$ & .866 & .012 & .250 \\
\hline
\end{tabular}

Note. Stand. Loading $=$ standardized factor loading, S.E. $=$ standard error, var $_{\mathrm{e}}=$ residual (error) variance. $(-)$ Negative construct. 
Table 8

Study 2 (Local Governance context) Latent Construct Correlations (Reliability [ $\omega]$ in the Diagonal)

\begin{tabular}{lccccccccccc}
\hline & 1 & 2 & 3 & 4 & 5 & 6 & 7 & 8 & 9 & 10 & 11 \\
\hline 1 - Disp. Trust & $\mathbf{( . 8 2 )}$ & & & & & & & & & & \\
2 - Direct/Unsp. & .424 & $\mathbf{( . 9 3 )}$ & & & & & & & & & \\
3 - Loyal Trust & .478 & .905 & $\mathbf{( . 8 4 )}$ & & & & & & & & \\
4 - Competence & .428 & .926 & .855 & $\mathbf{( . 8 7 )}$ & & & & & & & \\
5 - Legitimacy & .441 & .826 & .887 & .824 & $\mathbf{( . 8 7 )}$ & & & & & & \\
6 - Shared Values & .440 & .948 & .853 & .860 & .754 & $\mathbf{( . 9 1 )}$ & & & & & \\
7 - Cynical Beliefs(-) & -.404 & -.845 & -.774 & -.761 & -.764 & -.856 & $(.80)$ & & & & \\
8 - Care & .462 & .965 & .891 & .921 & .842 & .948 & -.874 & $\mathbf{( . 8 9 )}$ & & & \\
9- Voice & .419 & .897 & .815 & .837 & .786 & .878 & -.835 & .938 & $(.87)$ & & \\
$10-$ Honesty & .529 & .885 & .849 & .915 & .852 & .819 & -.803 & .924 & .820 & $(.82)$ & \\
$11-$ Fairness & .415 & .937 & .846 & .885 & .822 & .913 & -.836 & .939 & .890 & .864 & $(.87)$ \\
\hline
\end{tabular}

Note. All correlations are significant at the $\mathrm{p}<.05$ level. (-) Negatively valenced construct. 
Table 9

Results from Study 3 (Natural Resources Context) Confirmatory Factor Analyses

\begin{tabular}{|c|c|c|c|c|c|c|c|c|c|}
\hline Model & $\begin{array}{c}\text { Rescaled } \\
\Delta-2 \mathrm{LL} \\
\text { from } \mathrm{MF} \\
(\Delta d f)\end{array}$ & $X^{2}$ & $d f$ & CFI & TLI & $\begin{array}{l}\text { RMSEA } \\
(95 \% \mathrm{CI})\end{array}$ & SRMR & AIC & BIC \\
\hline \multicolumn{10}{|l|}{ Phase 1: A priori models } \\
\hline 1F: Compact model & $\begin{array}{c}1395.7 * \\
(45)\end{array}$ & 2983.728 & 527 & .796 & .783 & $\begin{array}{c}.086^{*} \\
(.083-.089)\end{array}$ & $.071 *$ & 54302.5 & 54756.9 \\
\hline 2F: Dispositional trust \& institutional trust & $\begin{array}{c}1017.5^{*} \\
(44)\end{array}$ & 2426.913 & 526 & .842 & .832 & $\begin{array}{c}.075^{*} \\
(.072-.078)\end{array}$ & $.060^{*}$ & 53521.7 & 53980.6 \\
\hline $\begin{array}{l}\text { 3F: Dispositional trust \& institutional trust } \\
\text { \& institutional trustworthiness }\end{array}$ & $\begin{array}{l}953.2^{*} \\
(42)\end{array}$ & 2343.391 & 524 & .849 & .839 & $\begin{array}{c}.074 * \\
(.071-.077)\end{array}$ & $.060^{*}$ & 53408.2 & 53876.0 \\
\hline $\begin{array}{l}\text { 4Fa: Dispositional trust \& institutional trust } \\
\text { \& ability/warmth trustworthiness }\end{array}$ & $\begin{array}{c}790.8^{*} \\
(39)\end{array}$ & 2147.714 & 521 & .865 & .855 & $\begin{array}{c}.070^{*} \\
(.067-.073)\end{array}$ & $.059^{*}$ & 53146.4 & 53627.5 \\
\hline $\begin{array}{l}\text { 4Fb: Dispositional trust \& institutional trust } \\
\text { \& positive/negative trustworthiness }\end{array}$ & $\begin{array}{c}444.9^{*} \\
(39)\end{array}$ & 1747.561 & 521 & .898 & .891 & $\begin{array}{c}.061^{*} \\
(.058-.064)\end{array}$ & $.045^{* *}$ & 52612.5 & 53093.7 \\
\hline $\begin{array}{l}\text { 5F: Dispositional trust \& institutional trust \& } \\
\text { ability/benevolence/integrity (ABI) }\end{array}$ & $\begin{array}{c}695.7 * \\
(35)\end{array}$ & 2044.676 & 517 & .873 & .863 & $\begin{array}{c}.068^{*} \\
(.065-.071)\end{array}$ & $.058 *$ & 53014.6 & 53513.6 \\
\hline $\begin{array}{l}\text { 6F: Dispositional trust \& institutional trust } \\
\text { \& ability/benevolence/integrity/values } \\
\text { (ABIV) }\end{array}$ & $\begin{array}{c}660.3^{*} \\
(30)\end{array}$ & 2009.157 & 512 & .876 & .864 & $\begin{array}{c}.068^{*} \\
(.065-.071)\end{array}$ & $.057^{*}$ & 52973.1 & 53494.4 \\
\hline MF: Many-factor model & N/A & 1240.765 & 482 & $.937^{*}$ & $.927^{*}$ & $\begin{array}{c}.050 * * \\
(.046-.053)\end{array}$ & $.038^{* *}$ & $51986.7 * *$ & $52641.6^{* *}$ \\
\hline \multicolumn{10}{|l|}{ Phase 2: Post hoc (data driven) models } \\
\hline PH-3F: DT \& Pos/Neg & $\begin{array}{l}520.1^{*} \\
(42)\end{array}$ & 1833.636 & 524 & .891 & .884 & $\begin{array}{c}.063^{*} \\
(.060-.066)\end{array}$ & $.045^{* *}$ & 52724.0 & 53191.8 \\
\hline PH-4F: DT \& Pos/Neg1/Neg2 & $\begin{array}{c}455.9^{*} \\
(39)\end{array}$ & 1752.732 & 521 & .898 & .890 & $\begin{array}{c}.061^{*} \\
(.058-.064)\end{array}$ & $.042^{* *}$ & 52615.2 & 53096.3 \\
\hline PH-HO1: Positive higher-order & $\begin{array}{c}355.1^{*} \\
(33)\end{array}$ & 1611.149 & 515 & $.909^{*}$ & $.901 *$ & $\begin{array}{c}.058 * * \\
(.055-.061)\end{array}$ & .137 & 52418.5 & 52926.3 \\
\hline PH-HO2: Pos \& Neg higher-order & $\begin{array}{c}427.2^{*} \\
(35) \\
\end{array}$ & 1681.873 & 517 & $.903^{*}$ & .895 & $\begin{array}{c}.060^{*} \\
(.056-.063) \\
\end{array}$ & .159 & 52506.3 & 53005.2 \\
\hline
\end{tabular}

Note. *Meets liberal criteria for goodness of fit, or $p<.05$ for rescaled $-2 \Delta$ LL test; **Meets conservative criteria for goodness of fit listed in text, or obtained best AIC/BIC of all tested models. 
Table 10

Study 3 (Natural Resources Context) Item Standardized Loadings from Best-Fitting (MF) Model

\begin{tabular}{|c|c|c|c|c|}
\hline Dimension & Item Wording & $\begin{array}{l}\text { Stand. } \\
\text { Loading }\end{array}$ & S.E. & $\operatorname{var}_{\mathrm{e}}$ \\
\hline \multirow{3}{*}{$\begin{array}{l}\text { Dispositional } \\
\text { Trust }\end{array}$} & 1. I would say that most people can be trusted in general. & .786 & .040 & .382 \\
\hline & 2. I think that most people try to be fair. & .970 & .037 & .060 \\
\hline & 3. I would say that most of the time people try to be helpful. & .600 & .038 & .640 \\
\hline \multirow{4}{*}{$\begin{array}{l}\text { Direct/ } \\
\text { Unspecified } \\
\text { Trust }\end{array}$} & 4. My confidence in Game \& Parks is high & .897 & .013 & 195 \\
\hline & 5. I have confidence in Game \& Parks to do its job & .895 & .016 & .199 \\
\hline & 6. I trust Game \& Parks to do its job well & .889 & .013 & .211 \\
\hline & 7. I trust Game \& Parks & .927 & .009 & .142 \\
\hline \multirow{4}{*}{ Competence } & $\begin{array}{l}\text { 8. Most decision makers of Game and Parks are competent to } \\
\text { do their jobs. }\end{array}$ & .856 & .023 & .267 \\
\hline & $\begin{array}{l}\text { 9. Most decision makers of Game and Parks are highly } \\
\text { qualified individuals. }\end{array}$ & .901 & .014 & .189 \\
\hline & $\begin{array}{l}\text { 10. Most Game \& Parks decision makers have the knowledge to } \\
\text { do their jobs }\end{array}$ & .906 & .014 & .180 \\
\hline & $\begin{array}{l}\text { 11. Most Game \& Parks decision makers have the skills to do } \\
\text { their jobs }\end{array}$ & .825 & .019 & .319 \\
\hline \multirow{4}{*}{ Legitimacy } & $\begin{array}{l}\text { 12. The decision makers of Game and Parks are selected using } \\
\text { fair procedures. }\end{array}$ & .760 & .027 & .423 \\
\hline & 13. The procedures followed by Game and Parks are lawful. & .653 & .040 & .574 \\
\hline & 14. Game and Parks uses its power appropriately. & .826 & .024 & .318 \\
\hline & $\begin{array}{l}\text { 15. Game and Parks is a legitimate authority on natural } \\
\text { resources regulation. }\end{array}$ & .738 & .029 & .455 \\
\hline \multirow{3}{*}{ Shared Values } & $\begin{array}{l}\text { 16. I believe Game and Parks shares my values about how } \\
\text { natural resources should be regulated }\end{array}$ & .828 & .019 & .314 \\
\hline & $\begin{array}{l}\text { 17. I share Game and Parks' values about how natural resources } \\
\text { should be regulated. }\end{array}$ & .831 & .023 & .309 \\
\hline & $\begin{array}{l}\text { 18. I believe that Game and Parks supports my values about } \\
\text { natural resources allocation. }\end{array}$ & 901 & .014 & .188 \\
\hline \multirow{4}{*}{ Cynical Beliefs (-) } & 19. Game and Parks does not protect my interests. & .839 & .019 & .297 \\
\hline & 20. Game and Parks is not representative of Nebraskans. & .756 & .036 & .429 \\
\hline & $\begin{array}{l}\text { 21. Game and Parks is out of touch with what's going on in its } \\
\text { communities. }\end{array}$ & .813 & .030 & .339 \\
\hline & $\begin{array}{l}\text { 22. The decision makers of Game \& Parks are primarily } \\
\text { motivated to do whatever they need to stay in power. }\end{array}$ & .631 & .038 & .602 \\
\hline \multirow{3}{*}{ Care } & $\begin{array}{l}\text { 23. For the most part, the decisions made by Game and Parks } \\
\text { are made out of care and concern for area residents. }\end{array}$ & .851 & .021 & .275 \\
\hline & residents in the area they regulate. & .639 & .038 & .592 \\
\hline & $\begin{array}{l}\text { 25. The decision makers of Game and Parks put aside their own } \\
\text { personal interests in making decisions that are right for the } \\
\text { community. }\end{array}$ & .779 & .022 & .393 \\
\hline \multirow{3}{*}{ Voice } & $\begin{array}{l}\text { 26. I feel like Game \& Parks listens to the opinions of people it } \\
\text { regulates. }\end{array}$ & .897 & .016 & .195 \\
\hline & 27. Residents have great say in important Game \& Parks & & & \\
\hline & $\begin{array}{l}\text { decisions. } \\
\text { 28. Citizens can influence Game \& Parks decisions. }\end{array}$ & $\begin{array}{l}.779 \\
.654\end{array}$ & $\begin{array}{l}.035 \\
.038\end{array}$ & $\begin{array}{l}.393 \\
.573\end{array}$ \\
\hline Fairness & $\begin{array}{l}\text { 29. The procedures by which Game and Parks decision makers } \\
\text { make decisions are fair. }\end{array}$ & .886 & .012 & .216 \\
\hline
\end{tabular}




\begin{tabular}{llrrr}
\hline Dimension & \multicolumn{1}{c}{ Item Wording } & $\begin{array}{c}\text { Stand. } \\
\text { Loading }\end{array}$ & S.E. & var \\
\hline & $\begin{array}{l}\text { 30. In my experience, Game and Parks generally has been fair in } \\
\text { their dealings with the community. }\end{array}$ & .804 & .025 & .354 \\
& 31. I have generally been treated fair by Game and Parks. & .725 & .028 & .474 \\
\hline & $\begin{array}{l}\text { 32. I think Game \& Parks acts in the interests of some groups } \\
\text { over others. }\end{array}$ & .709 & .033 & .498 \\
Bias (-) & $\begin{array}{l}\text { 33. The decisions made by Game \& Parks are biased. } \\
\text { 34. Game \& Parks is overly influenced by special interest } \\
\text { groups. }\end{array}$ & .752 & .034 & .434 \\
&
\end{tabular}

Note. Stand. Loading $=$ standardized factor loading, S.E. $=$ standard error, $\operatorname{var}_{\mathrm{e}}=$ residual (error) variance. $(-)$ Negative construct. 
Table 11

Study 3 (Natural Resources Context) Latent Construct Correlations (Reliability [W] on the Diagonal)

\begin{tabular}{lllllllllll}
\hline & 1 & 2 & 3 & 4 & 5 & 6 & 7 & 8 & 9 & 10 \\
\hline 1 - Dispositional Trust & $\mathbf{( . 8 5 )}$ & & & & & & & & & \\
2 - Direct/Unspec. Trust & .159 & $\mathbf{( . 9 5 )}$ & & & & & & & & \\
3 - Competence & .112 & .882 & $\mathbf{( . 9 3 )}$ & & & & & & & \\
4 - Legitimacy & .120 & .894 & .913 & $\mathbf{( . 8 4 )}$ & & & & & & \\
5 - Shared Values & .116 & .922 & .847 & .876 & $\mathbf{( . 8 9 )}$ & & & & & \\
6 - Cynical Beliefs (-) & $-.119^{\text {ns }}$ & -.721 & -.650 & -.702 & -.710 & $(.85)$ & & & & \\
7 - Care & .102 & .978 & .906 & .892 & .932 & -.714 & $(.81)$ & & & \\
8 - Voice & .120 & .888 & .814 & .827 & .849 & -.650 & .934 & $(.82)$ & & \\
9 - Fairness & .140 & .935 & .938 & .942 & .922 & -.744 & .940 & .869 & $(.85)$ & \\
10 - Bias (-) & -.127 & -.574 & -.485 & -.504 & -.585 & .803 & -.591 & -.554 & -.562 & $(.79)$ \\
\hline
\end{tabular}

Note. ${ }^{\text {ns }}$ Non-significant correlation. All other correlations are significant at the $p<.05$ level.

(-) Negatively valenced construct. 
Table 12

Results from Study 4 (State Government Context) Confirmatory Factor Analyses (CFAs) of Trustworthiness (TW) constructs only

\begin{tabular}{|c|c|c|c|c|c|c|c|c|c|}
\hline Model & $\begin{array}{l}\text { Rescaled } \\
\Delta-2 \mathrm{LL} \\
\text { from TWMF } \\
\qquad(\Delta d f)\end{array}$ & $X^{2}$ & $d f$ & CFI & TLI & $\begin{array}{l}\text { RMSEA } \\
(95 \% \mathrm{CI})\end{array}$ & SRMR & AIC & $\mathrm{BIC}$ \\
\hline \multicolumn{10}{|l|}{ Phase 1: A priori Models } \\
\hline TW-1F: Compact model & $\begin{array}{c}1327.5^{*} \\
(36)\end{array}$ & 2563.809 & 377 & .677 & .652 & $\begin{array}{c}.121 \\
(.116-.125)\end{array}$ & .080 & 36338.8 & 36685.9 \\
\hline TW-2Fa: Ability/warmth trustworthiness & $\begin{array}{l}1214.3^{*} \\
(35)\end{array}$ & 2336.985 & 376 & .711 & .687 & $\begin{array}{c}.114 \\
(.110-.119)\end{array}$ & .088 & 36024.2 & 36375.3 \\
\hline $\begin{array}{l}\text { TW-2Fb: Positive/negative } \\
\text { trustworthiness }\end{array}$ & $\begin{array}{l}1127.9^{*} \\
(35)\end{array}$ & 2213.194 & 376 & .729 & .707 & $\begin{array}{c}.111 \\
(.106-.115)\end{array}$ & $.072 *$ & 35862.7 & 36213.8 \\
\hline $\begin{array}{l}\text { TW-3F: Ability/benevolence/integrity } \\
\text { (ABI) trustworthiness }\end{array}$ & $\begin{array}{l}1170.27 * \\
(33)\end{array}$ & 2277.697 & 374 & .719 & .695 & $\begin{array}{c}.113 \\
(.109-.117)\end{array}$ & .087 & 35945.9 & 36304.9 \\
\hline $\begin{array}{l}\text { TW-4F: Ability/ benevolence/ integrity/ } \\
\text { values (ABIV) trustworthiness }\end{array}$ & $\begin{array}{c}1216.5^{*} \\
(30)\end{array}$ & 2256.321 & 371 & .722 & .696 & $\begin{array}{c}.113 \\
(.108-.117)\end{array}$ & .086 & 35897.4 & 36268.4 \\
\hline $\begin{array}{l}\text { TW-MF: Many-factor trustworthiness } \\
\text { model }\end{array}$ & N/A & 762.790 & 341 & $.938 *$ & $.926 *$ & $\begin{array}{c}.056 * * \\
(.050-.061)\end{array}$ & $.049 * *$ & 34044.9 & 34535.6 \\
\hline \multicolumn{10}{|l|}{ Phase 2: Post hoc (data driven) models } \\
\hline $\begin{array}{l}\text { PH-TW-8F: cynical and impartiality items } \\
\text { collapsed to single factor }\end{array}$ & $\begin{array}{l}151.0 * \\
(8)\end{array}$ & 921.911 & 349 & $.915^{*}$ & $.902 *$ & $\begin{array}{c}.064 * \\
(.059-.069)\end{array}$ & $.053 *$ & 34227.8 & 34686.6 \\
\hline $\begin{array}{l}\text { PH-TW-7F: legitimacy, voice, and } \\
\text { fairness items collapsed to a single } \\
\text { factor }\end{array}$ & $\begin{array}{c}58.4^{*} \\
(15)\end{array}$ & 825.506 & 356 & $.931 *$ & $.921 *$ & $\begin{array}{c}.057 * * \\
(.052-.063)\end{array}$ & $.050^{*}$ & 34100.7 & 34531.5 \\
\hline $\begin{array}{l}\text { PH-TW-6F: collapse both the negative } \\
\text { items and legit/voice/fair items }\end{array}$ & $\begin{array}{c}199.9 * \\
(21)\end{array}$ & 983.716 & 362 & $.908^{*}$ & .897 & $\begin{array}{c}.066^{*} \\
(.061-.071)\end{array}$ & $0.054 *$ & 34287.3 & 34694.2 \\
\hline $\begin{array}{l}\text { PH-TW-1HOa: Higher-order factor for } \\
\text { negative constructs }\end{array}$ & $\begin{array}{l}7.1 \\
(6)\end{array}$ & 770.307 & 347 & $.938^{*}$ & $.927 *$ & $\begin{array}{c}.055^{* *} \\
(.050-.061)\end{array}$ & $.049 * *$ & 34041.1 & 34507.8 \\
\hline $\begin{array}{l}\text { PH-TW-1HOb: Higher-order factor for } \\
\text { legitimacy, fairness, and voice } \\
\text { constructs }\end{array}$ & $\begin{array}{l}3.6 \\
(12)\end{array}$ & 764.371 & 353 & $.939 *$ & $.930 *$ & $\begin{array}{c}.054 * * \\
(.049-.059)\end{array}$ & $.049 * *$ & 34025.7 & 34468.5 \\
\hline $\begin{array}{l}\text { PH-TW-2HO: Both higher-order factors } \\
\text { described above }\end{array}$ & $\begin{array}{l}9.6 \\
(16)\end{array}$ & 771.338 & 357 & $.939 *$ & $.930 *$ & $\begin{array}{c}054 * * \\
(.049-.059)\end{array}$ & $.050^{*}$ & $34025.3 * *$ & $34452.1 * *$ \\
\hline
\end{tabular}

Note. *Meets liberal criteria for goodness of fit, or $p<.05$ for rescaled $-2 \Delta$ LL test; $* *$ Meets conservative criteria for goodness of fit listed in text, or obtained best AIC/BIC of all tested models. 
Table 13

Study 4 (State Government Context) Item Standardized Loadings for Best-Fitting (MF) Model

\begin{tabular}{|c|c|c|c|c|}
\hline Dimension & Item Wording & $\begin{array}{c}\text { Stand. } \\
\text { Loading }\end{array}$ & S.E. & $\operatorname{var}_{e}$ \\
\hline \multirow{4}{*}{ Competence } & $\begin{array}{l}\text { 1. Most decision makers in the state government have the } \\
\text { skills necessary to do their jobs. }\end{array}$ & .884 & .020 & .219 \\
\hline & $\begin{array}{l}\text { 2. Most decision makers in the state government have the } \\
\text { knowledge necessary to do their jobs. }\end{array}$ & .868 & .019 & .247 \\
\hline & $\begin{array}{l}\text { 3. Most decision makers of the state government are highly } \\
\text { qualified individuals. }\end{array}$ & .849 & .021 & .279 \\
\hline & $\begin{array}{l}\text { 4. Most decision makers of the state government are } \\
\text { competent to do their jobs. }\end{array}$ & .834 & .028 & .305 \\
\hline \multirow{4}{*}{ Legitimacy } & $\begin{array}{l}\text { 5. The procedures followed by the state government are } \\
\text { lawful. }\end{array}$ & .641 & .042 & .589 \\
\hline & $\begin{array}{l}\text { 6. The decision makers of the state government are selected } \\
\text { using fair procedures. }\end{array}$ & .683 & .035 & .533 \\
\hline & $\begin{array}{l}\text { 7. The state government is a legitimate authority on energy } \\
\text { policy. }\end{array}$ & .603 & .042 & .637 \\
\hline & 8. The state government uses its power appropriately. & .832 & .025 & .308 \\
\hline \multirow{3}{*}{ Shared Values } & $\begin{array}{l}\text { 9. I believe the state government shares my values about } \\
\text { energy policy. }\end{array}$ & .961 & .008 & .076 \\
\hline & $\begin{array}{l}\text { 10.I believe that the state government supports my values } \\
\text { about energy policy. }\end{array}$ & .949 & .012 & .099 \\
\hline & $\begin{array}{l}\text { 11. To the extent that I understand them, I share the state } \\
\text { government's values about how energy should be } \\
\text { regulated. }\end{array}$ & .747 & .039 & .241 \\
\hline \multirow{4}{*}{ Cynical Beliefs (-) } & $\begin{array}{l}\text { 12. The state government is out of touch with what's going on } \\
\text { in its communities. }\end{array}$ & .869 & .021 & .245 \\
\hline & $\begin{array}{l}\text { 13. The state government is not representative of its } \\
\text { communities. }\end{array}$ & .828 & .027 & .315 \\
\hline & $\begin{array}{l}\text { 14. The decision makers of the state government are primarily } \\
\text { motivated to do whatever they need to stay in power. }\end{array}$ & .756 & .030 & .428 \\
\hline & 15. The state government does not protect my interests. & .815 & .025 & .336 \\
\hline \multirow{3}{*}{ Care } & $\begin{array}{l}\text { 16. The decision makers of the state government put aside } \\
\text { their own personal interests in making decisions that are } \\
\text { right for the community. }\end{array}$ & .668 & .039 & .554 \\
\hline & $\begin{array}{l}\text { 17. For the most part, the decisions made by the state } \\
\text { government are made out of care and concern for residents } \\
\text { in the area they work. }\end{array}$ & .897 & .020 & .196 \\
\hline & $\begin{array}{l}\text { 18. Most decision makers of the state government care about } \\
\text { residents in the area they work. }\end{array}$ & .894 & .018 & .201 \\
\hline \multirow{3}{*}{ Voice } & $\begin{array}{l}\text { 19.I feel like the state government listens to the opinions of } \\
\text { the people it works with. }\end{array}$ & .868 & .026 & .246 \\
\hline & 20. Citizens can influence the state government's decisions. & .650 & .045 & .577 \\
\hline & $\begin{array}{l}\text { 21. Residents have great say in important state government } \\
\text { decisions. }\end{array}$ & .747 & .039 & .442 \\
\hline \multirow[t]{2}{*}{ Honesty } & $\begin{array}{l}\text { 22. The state government is made up of mostly honest } \\
\text { individuals. }\end{array}$ & .770 & .045 & .407 \\
\hline & 23. Most officials in the state government lack integrity. (r) & .823 & .033 & .323 \\
\hline \multirow[t]{2}{*}{ Fairness } & $\begin{array}{l}\text { 24.In my experience, the state government generally has been } \\
\text { fair in their dealings with the community. }\end{array}$ & .090 & .016 & .197 \\
\hline & 25.I have generally been treated fair by the state government. & .766 & .026 & .414 \\
\hline
\end{tabular}




\begin{tabular}{llccc}
\hline Dimension & \multicolumn{1}{c}{ Item Wording } & $\begin{array}{c}\text { Stand. } \\
\text { Loading }\end{array}$ & S.E. & var $_{\mathrm{e}}$ \\
\hline & $\begin{array}{l}\text { 26. The procedures by which the state government makes } \\
\text { decisions are fair. }\end{array}$ & .842 & .023 & .290 \\
\hline & $\begin{array}{l}\text { 27.I think the state government acts in the interests of some } \\
\text { groups over others. }\end{array}$ & .850 & .024 & .277 \\
Bias (-) & $\begin{array}{l}\text { 28. The decisions made by the state government are biased. } \\
\text { 29. The state government is overly influenced by special } \\
\text { interest groups. }\end{array}$ & .874 & .022 & .236 \\
\end{tabular}

Note. Stand. Loading $=$ standardized factor loading, S.E. $=$ standard error, var $_{\mathrm{e}}=$ residual (error) variance.

(-) Negative construct. 
Table 14

Study 4 (State Government Context) Latent Construct Correlations (Reliability [w] in the Diagonal)

\begin{tabular}{|c|c|c|c|c|c|c|c|c|c|}
\hline & 1 & 2 & 3 & 4 & 5 & 6 & 7 & 8 & 9 \\
\hline 1 -Competence & $(.92)$ & & & & & & & & \\
\hline 2 - Legitimacy & .719 & $(.79)$ & & & & & & & \\
\hline 3 - Shared Values & .498 & .682 & $(.95)$ & & & & & & \\
\hline 4 - Cynical Beliefs (-) & -.584 & -.763 & -.536 & $(.89)$ & & & & & \\
\hline 5 - Care & .622 & .700 & .522 & -.677 & (.86) & & & & \\
\hline $6-$ Voice & .663 & .866 & .691 & -.750 & .698 & $(.80)$ & & & \\
\hline 7 - Honesty & .611 & .755 & .500 & -.799 & .738 & .759 & $(.78)$ & & \\
\hline 8 - Fairness & .685 & .903 & .698 & -.759 & .707 & .870 & .775 & $(.87)$ & \\
\hline $9-\operatorname{Bias}(-)$ & -.480 & -.574 & -.457 & .782 & -.545 & -.589 & -.691 & -.592 & $(.87)$ \\
\hline
\end{tabular}

Note. All correlations are significant at the $p<.05$ level. (-) Negatively valenced construct. 
Figure 1. Nestedness of alternative a priori models

Note. See text and Table 1 for model definitions. Each model nested within another is created by adding constraints to (estimating a subset of the parameters of) the more complex model.

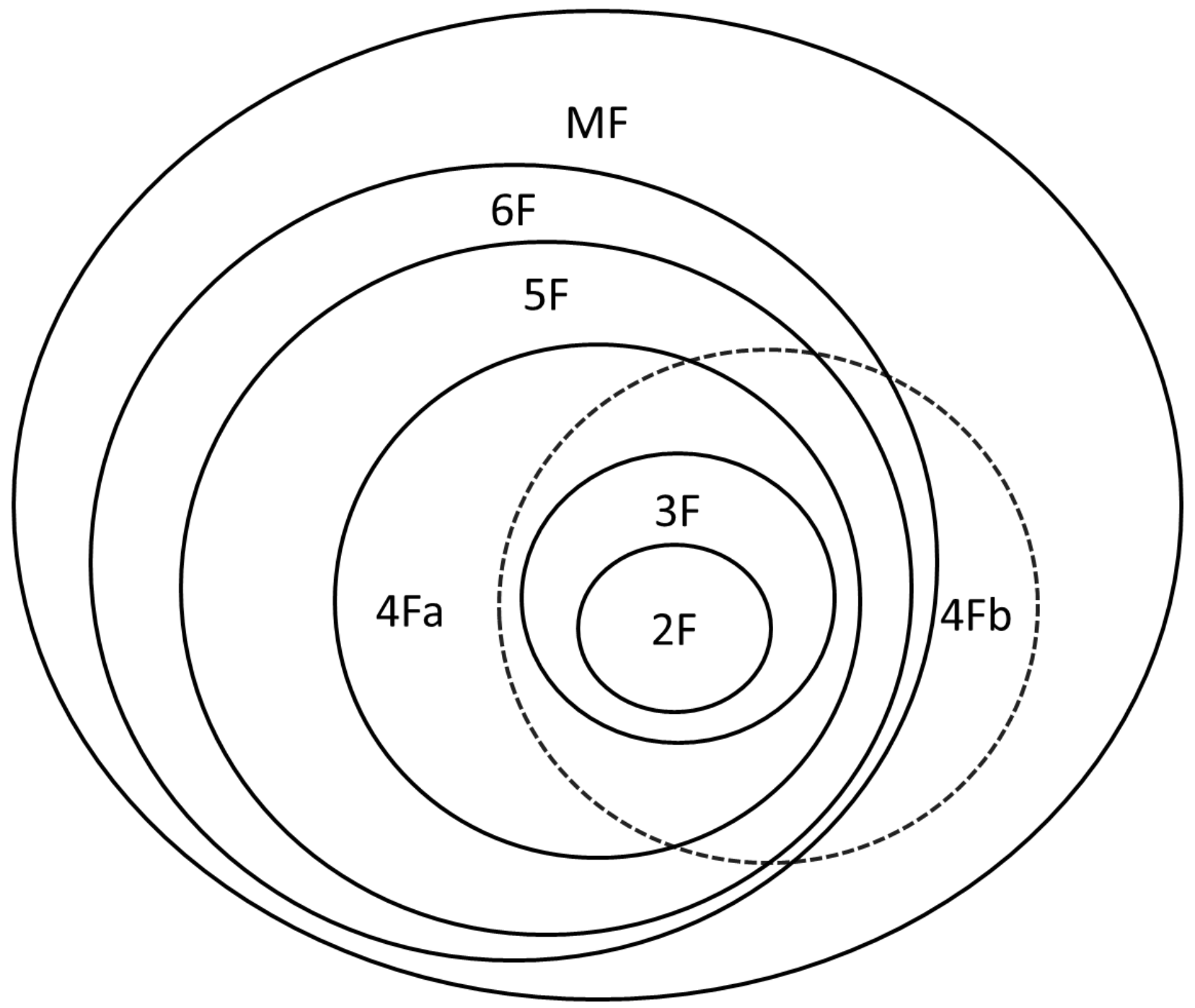

